Prepared in cooperation with the

LOWER PLATTE SOUTH NATURAL RESOURCES DISTRICT

\title{
Temporal Differences in the Hydrologic Regime of the Lower Platte River, Nebraska, 1895-2006
}

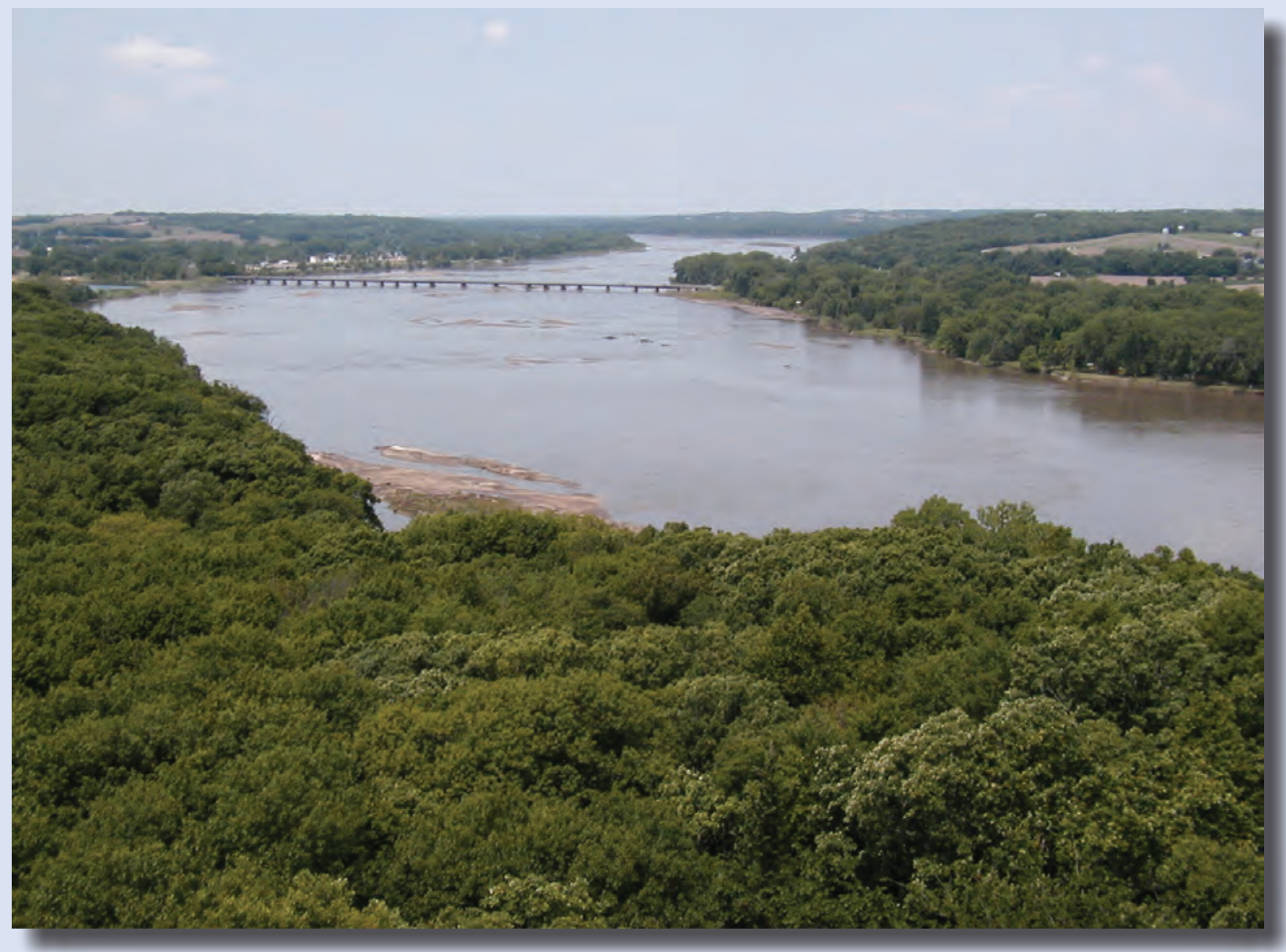

Scientific Investigations Report 2007-5267 
Front cover.-Photograph of the Platte River looking upstream toward the Lied Bridge from the observation tower at the Platte River State Park, May 26, 2003 (photograph taken by Ronald B. Zelt, U.S. Geological Survey, Lincoln, Nebraska). 


\section{Temporal Differences in the Hydrologic Regime of the Lower Platte River, Nebraska, 1895-2006}

By Daniel Ginting, Ronald B. Zelt, and Joshua I. Linard

Prepared in cooperation with the Lower Platte South Natural Resources District

Scientific Investigations Report 2007-5267 


\section{U.S. Department of the Interior DIRK KEMPTHORNE, Secretary}

\section{U.S. Geological Survey \\ Mark D. Myers, Director}

\section{U.S. Geological Survey, Reston, Virginia: 2008}

For product and ordering information:

World Wide Web: http://www.usgs.gov/pubprod

Telephone: 1-888-ASK-USGS

For more information on the USGS — the Federal source for science about the Earth, its natural and living resources, natural hazards, and the environment:

World Wide Web: http://www.usgs.gov

Telephone: 1-888-ASK-USGS

Any use of trade, product, or firm names is for descriptive purposes only and does not imply endorsement by the U.S. Government.

Although this report is in the public domain, permission must be secured from the individual copyright owners to reproduce any copyrighted materials contained within this report.

Suggested citation:

Ginting, Daniel, Zelt, R.B., and Linard, J.I. , 2008, Temporal Differences in the Hydrologic Regime of the Lower Platte River, Nebraska, 1895-2006: U.S. Geological Survey Scientific Investigations Report 2007-5267, 43 p. 


\section{Contents}

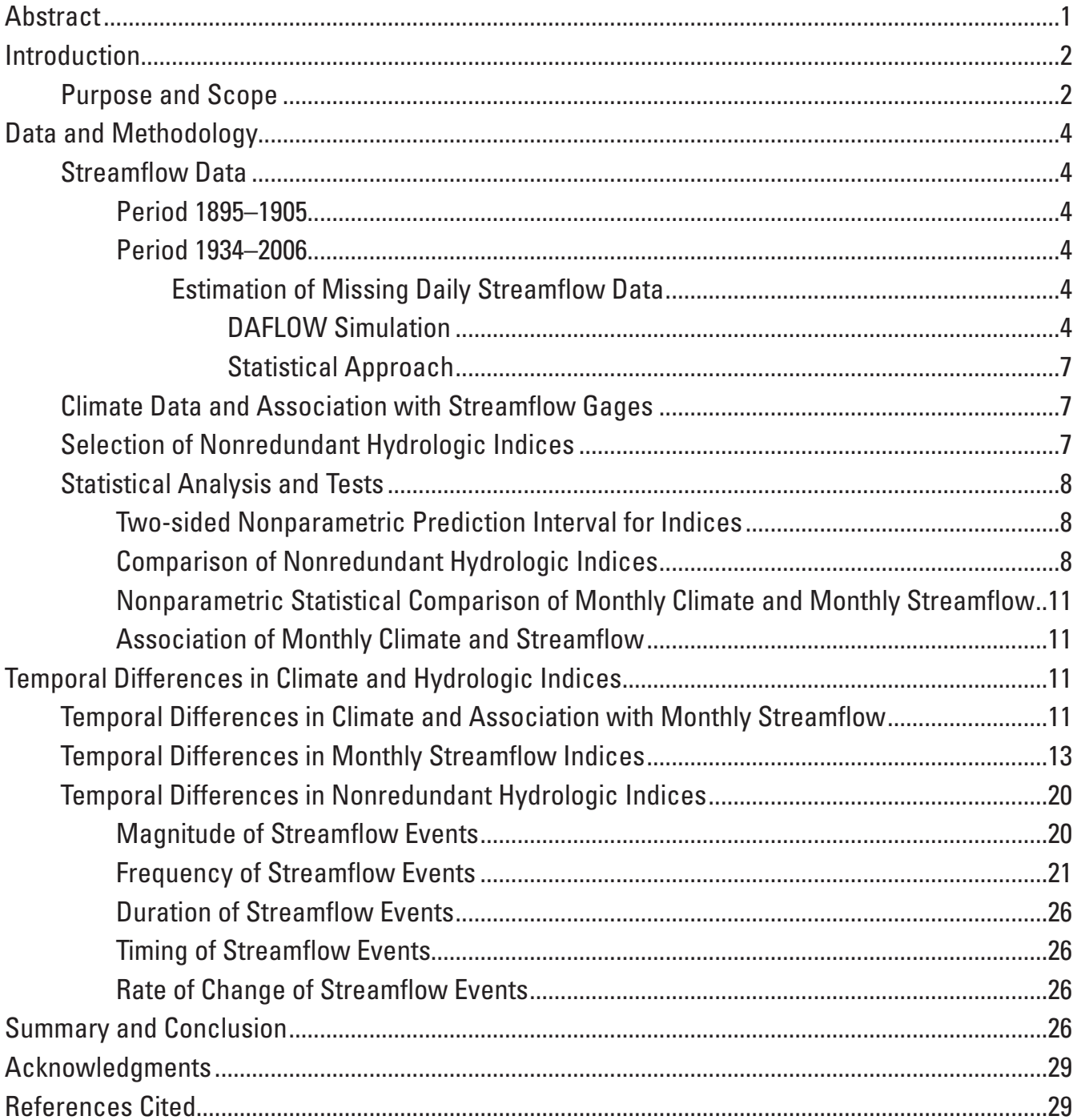

\section{Appendixes}

1. Lower and upper quartile values of monthly precipitation for the 11-water-year periods for four Nebraska climate divisions drained by the lower Platte River from Duncan through Louisville, Nebraska, 1895-2006 ........................................................................32

2. Lower and upper quartile values of monthly Palmer Hydrological Drought Index, by climate division and 11-water-year period, for four Nebraska climate divisions drained by the lower Platte River from Duncan through Louisville, Nebraska, 1895-2006...........33

3. Lower and upper quartile values of monthly mean streamflow, by station and 11water-year period, for the Platte River gaging stations from Duncan through Louisville, Nebraska, 1895-2006.

4. Lower and upper quartile values of monthly maximum streamflow, by station and 11water-year period, for the Platte River gaging stations from Duncan through Louisville, Nebraska, 1895-2006. 
5. Lower and upper quartile values of monthly minimum streamflow, by station and 11-water-year period, for the Platte River gaging stations from Duncan through Louisville, Nebraska, 1895-2006

6. Lower and upper quartile values of monthly coefficients of skewness of streamflow distribution, by station and 11-water-year period, for the Platte River gaging stations from Duncan through Louisville, Nebraska, 1895-2006.

7. Lower and upper quartile values of monthly coefficient of variation of streamflow, by station and 11-water-year period, for the Platte River gaging stations from Duncan through Louisville, Nebraska, 1895-2006.

\section{Figures}

1. Location of study area and gaging stations on the Platte River and contributing tributaries, Nebraska .

2. Sequence of data analysis for hydrologic indices..........................................................11

3. Daily streamflow hydrograph for the central Platte River system near Duncan, Nebraska, during the 1934-44 drought period.

4. Daily streamflow hydrograph for the central Platte River system near Duncan, Nebraska during the 1985-95 moderately wet period

\section{Tables}

1. Completeness of available records of daily streamflow at selected gaging stations on the Platte River, Nebraska

2. Completeness of available records of daily streamflow at selected gaging stations on the tributaries of the lower Platte River, Nebraska..

3. Definition and alphanumeric code of the monthly streamflow indices and the nonredundant hydrologic indices for the Platte River from Duncan through Louisville, Nebraska

4. Median value and rank comparisons among selected time periods of monthly precipitation for four climate divisions drained by the Platte River from Duncan through Louisville, Nebraska, 1895-2006.

5. Median value and rank comparisons among selected time periods of monthly Palmer Hydrological Drought Index for four climate divisions drained by the Platte River from Duncan through Louisville, Nebraska, 1895-2006.

6. Kendall's tau rank correlation of monthly streamflow with monthly precipitation and monthly Palmer Hydrological Drought Indices for four climatic divisions drained by the Platte River from Duncan through Louisville, Nebraska, 1895-2006.

7. Median value and rank comparisons among selected time periods of monthly mean streamflow at the Platte River gaging stations near Duncan, North Bend, Leshara, Ashland, and Louisville, Nebraska, 1895-2006

8. Median value and rank comparisons among selected time periods of monthly maximum streamflow at the Platte River gaging stations near Duncan, North Bend, Leshara, Ashland, and Louisville, Nebraska, 1895-2006.

9. Median value and rank comparisons among selected time periods of monthly minimum streamflow at the Platte River gaging stations near Duncan, North Bend, Leshara, Ashland, and Louisville, Nebraska, 1895-2006 
10. Median value and rank comparisons among selected time periods of monthly coefficients of skewness of streamflow at the Platte River gaging stations near Duncan, North Bend, Leshara, Ashland, and Louisville, Nebraska, 1895-2006 22

11. Median value and rank comparisons among selected time periods of monthly coefficient of variation of streamflow at the Platte River gaging stations near Duncan, North Bend, Leshara, Ashland, and Louisville, Nebraska, 1895-2006

12. Existence of probable temporal differences in nonredundant hydrologic indices of streamflow-regime categories for Platte River gaging stations near Duncan, North Bend, Leshara, Ashland, and Louisville, Nebraska, 1934-2006

13. Nonredundant hydrologic indices of streamflow magnitude and frequency at the Platte River gaging stations near Duncan, North Bend, Leshara, Ashland, and Louisville, Nebraska, 1934-2006...

14. Nonredundant hydrologic indices of streamflow duration at the Platte River gaging stations near Duncan, North Bend, Leshara, Ashland, and Louisville, Nebraska, 1934-2006.

15. Nonredundant hydrologic indices of streamflow timing and rate of change at the Platte River gaging stations near Duncan, North Bend, Leshara, Ashland, and Louisville, Nebraska, 1934-2006.

\section{Conversion Factors}

\begin{tabular}{lcc}
\hline \multicolumn{1}{c}{ Multiply } & By & To obtain \\
\hline inch (in.) & Length \\
\hline \multicolumn{3}{c}{ Flow rate } \\
\hline cubic foot per second $\left(\mathrm{ft}^{3} / \mathrm{s}\right)$ & 0.02832 & cubic meter per second $\left(\mathrm{m}^{3} / \mathrm{s}\right)$ \\
\hline \multicolumn{3}{c}{ Flow fall/rise rate } \\
\hline $\begin{array}{c}\text { cubic foot per second per day } \\
{\left[\left(\mathrm{ft}^{3} / \mathrm{s}\right) / \text { day }\right]}\end{array}$ & 0.02832 & $\begin{array}{c}\text { cubic meter per second per day } \\
{\left[\left(\mathrm{m}^{3} / \mathrm{s}\right) / \text { day }\right]}\end{array}$ \\
\hline
\end{tabular}

Water year is defined as the 12-month period October 1 through September 30.

The water year is designated by the calendar year in which it ends.

\section{Acronyms}

$\begin{array}{ll}\text { CIS } & \text { cumulative impact study } \\ \text { CV } & \text { coefficient of variation } \\ \text { HI } & \text { hydrologic index } \\ \text { HIP } & \text { hydroecological integrity assessment process } \\ \text { NCDC } & \text { National Climate Data Center } \\ \text { PCA } & \text { principal component analysis } \\ \text { PHDI } & \text { Palmer Hydrological Drought Index } \\ \text { USGS } & \text { U.S. Geological Survey }\end{array}$





\title{
Temporal Differences in the Hydrologic Regime of the Lower Platte River, Nebraska, 1895-2006
}

\author{
By Daniel Ginting, Ronald B. Zelt, and Joshua I. Linard
}

\section{Abstract}

In cooperation with the Lower Platte South Natural Resources District for a collaborative study of the cumulative effects of water and channel management practices on stream and riparian ecology, the U.S. Geological Survey (USGS) compiled, analyzed, and summarized hydrologic information from long-term gaging stations on the lower Platte River to determine any significant temporal differences among six discrete periods during 1895-2006 and to interpret any significant changes in relation to changes in climatic conditions or other factors. A subset of 171 examined hydrologic indices (HIs) were selected for use as indices that (1) included most of the variance in the larger set of indices, (2) retained utility as indicators of the streamflow regime, and (3) provided information at spatial and temporal scale(s) that were most indicative of streamflow regime(s). The study included the most downstream station within the central Platte River segment that flowed to the confluence with the Loup River and all four active streamflow-gaging stations (2006) on the lower Platte River main stem extending from the confluence of the Loup River and Platte River to the confluence of the Platte River and Missouri River south of Omaha. The drainage areas of the five streamflow-gaging stations covered four (of eight) climate divisions in Nebraska-division 2 (north central), 3 (northeast), 5 (central), and 6 (east central).

Historical climate data and daily streamflow records from 1895 through 2006 at the five streamflow-gaging stations were divided into six 11-water-year periods: 1895-1905, 1934-44, 1951-61, 1966-76, 1985-95, and 1996-2006. Analysis of monthly climate variables_-precipitation and Palmer Hydrological Drought Index - was used to determine the degree of hydroclimatic association between streamflow and climate. Except for the 1895-1905 period, data gaps in the streamflow record were filled by data estimation techniques, and 171 hydrologic indices were calculated using the Hydroecological Integrity Assessment Process software developed by the U.S. Geological Survey. A subset of 27 nonredundant indices (of the 171 indices) was selected using principal component analysis. Indices that described monthly streamflow-mean, maximum, minimum, skewness, and coefficients of variation-also were used. Comparison of these selected indices allowed determination of temporal differences among the six 11-water-year periods for each gaging station.

The lower Platte River basin was affected by moderate to severe drought conditions in the $1934-44$ period. The widespread drought was preceded by mildly to moderately wet conditions in the 1895-1906 period, followed by incipient drought to incipiently wet conditions in the 1951-61 periods and mildly wet conditions in 1966-76 period, moderately wet conditions in the 1985-1995 period, and incipient drought to mildly wet conditions in the 1996-2006 period. Monthly streamflow of the Platte River from Duncan through Louisville, Nebraska, correlated significantly with the monthly Palmer Hydrological Drought Index. Temporal differences in median values of monthly-mean and monthly-maximum streamflow measured at Duncan, North Bend, and Ashland stations between the two moderately wet periods (1895-1905 and 1985-95) indicated that streamflow storage reservoirs and regulation some time after 1906 significantly reduced monthly streamflow magnitude and amplitude - the difference between the highest and lowest median values of monthly mean streamflow. Effects of storage reservoirs on the median values of monthly-minimum streamflow were less obvious. Temporal differences among the other five periods, from 1934 through 2006 when streamflow was affected by storage and regulation, indicated the predominant effects of contrasting climate conditions on median values of monthly mean, maximum, and minimum streamflow. Significant temporal differences in monthly streamflow values were evident mainly between the two periods of greatly contrasting climate conditions: the monthly flows in the 1934-44 drought period were significantly lower than those in the 1985-96 moderately wet period.

The monthly coefficients of skewness and variation of streamflow, and the counts of nonredundant indices showing temporal differences among the periods, together pointed to difference in streamflow regimes between the central Platte River system and the lower Platte River system. Seven out of 13 indices of the discharge from the central Platte River system at Duncan station that demonstrated potential temporal differences were indices of streamflow variability; five of nine indices for two or more of the lower Platte River stations that showed potential temporal differences were indices of streamflow variability. The nonredundant indices of the streamflow regime from the central Platte River system computed for Duncan station during the 1934-44 and 1951-61 periods had 
potential differences from the other periods, that is, the largest variability in base flow and monthly minimum streamflow values, highest frequency of low-flow pulses, lowest flood frequency, largest number and least variability of zero-flow days, and largest variability of the daily and monthly flows.

Nonredundant indices for the lower Platte River that demonstrated potential temporal differences at two or more stations were: high-peak streamflow, variability in low-flood pulse count, variability in high-flow pulse count, flood frequency, annual minimum daily streamflow, variability in lowflow pulse duration, variability of annual maximum of 1-day moving average streamflow, variability of annual maximum of 3-day moving average streamflow, and number of streamflow fluctuations. The variability in low-flood pulse count and variability in high-flow pulse count were generally highest in the 1996-2006 period because this period was a mixture of five wet years (1996-2000) and six drought years. The number of streamflow fluctuations was higher in the 1966-76, 1985-95, and 1996-2006 periods than those in the 1934-44 and 1951-61 periods for the North Bend and Leshara stations, which was associated with climate and increasing water regulation and management.

\section{Introduction}

Physical processes that control the streamflow regime and channel characteristics govern the distribution of habitat availability and quality for fish (Moir and others, 1998), and similarly may affect nesting habitat for shore birds (Dinan and others, 1993). Fish and other aquatic organisms in lotic water bodies are subjected to a wide range of streamflow, and the spatially and temporally dynamic nature of current hydraulics and micro-scale velocity patterns that arise from the interaction between streamflow and channel form (Stalnaker and others, 1996). Supply, delivery, and quality of both runoff and sediment affect aquatic habitat through the influences of channel gradient and streamflow (McKenney, 1997; Moir and others, 1998) and through influences of bed substrate characteristics, hydraulic obstructions, and turbulent vortices (McKenney, 1997; Fitzpatrick and others, 1998); therefore, even moderate changes in streamflow regime can produce large shifts in available habitat (Nebraska Game and Parks Commission, 1993; Stalnaker and others, 1996; McKenney, 1997). Pallid sturgeon, which prefers turbid main-channel habitats, has experienced population declines linked to alterations in the natural flow regimes of its native rivers (Dryer and Sandvol, 1993).

The lower Platte River ecosystem provides riverine habitat for forage, reproduction, or living space of resident and migratory fish and wildlife species including state- and federally listed endangered species, that is, pallid sturgeon, piping plover, interior least tern, and river otter (Nebraska Game and Parks Commission, 1993; U.S. Fish and Wildlife Service 1990, 1994). Considering the importance of the lower Platte
River ecosystem, a cumulative impact study (CIS) for the lower Platte River was deemed necessary. A CIS consortium was formed to include both federal (U.S. Geological Survey, U.S. Army Corps of Engineers, and U.S. Fish and Wildlife Service) and Nebraska institutions (Lower Platte River Corridor Alliance, Nebraska Environmental Trust, Nebraska Game and Parks Commission, Nebraska Department of Natural Resources, Nebraska Department of Roads, three Natural Resources Districts, and the University of Nebraska-Lincoln). The goal of the consortium was to analyze past, present, and future changes in infrastructure, land use, river management, and hydrology to understand how each of these general factors is interrelated to the river, its floodplain, and the bluff-to-bluff corridor. As part of this consortium, the U.S. Geological Survey (USGS) compiled, analyzed, and summarized hydrologic information from long-term gaging stations on the lower Platte River to determine any significant temporal differences among targeted time periods and to interpret any significant changes in relation to changes in climatic conditions or other factors.

Hydrologic indices that are ecologically and biologically relevant are needed to address the temporal changes in hydrologic conditions (National Research Council, 2005). Therefore, researchers have developed and examined a large number of hydrologic indices to describe various characteristics of streamflow that are biologically relevant. Olden and Poff (2003) examined 171 hydrologic indices (HIs) simultaneously to select a list of highly informative and nonredundant indices for six different types of streams. These indices can be used to make quantitative comparisons among segments of the same river or to track changes in the condition of rivers over time in response to regulatory programs, management practices, or climate variations (National Research Council, 2005).

\section{Purpose and Scope}

The purpose of this report is to present the temporal differences in hydrologic indices for the lower Platte River, Nebraska, for six discrete periods from 1895 through 2006. A subset of 171 examined HIs were selected for use as indices that (1) included most of the variance in the larger set of indices, (2) retained utility as indicators of the streamflow regime, and (3) provided information at the spatial and temporal scale(s) that were most indicative of streamflow regime(s). Hydrologic indices examined in this study included the five major categories of the flow regime-magnitude, duration, frequency, timing, and rate of change (Poff and Ward, 1989; Poff and others, 1997).

The lower Platte River is defined as the segment extending from the confluence of the Loup River and Platte River to the confluence of the Platte River and Missouri River south of Omaha, Nebraska (fig. 1), which receives streamflow primarily from four (of eight) climate divisions in Nebraska (National Climatic Data Center, 2007). The scope of this report included all four active (2006) lower Platte River mainstem stations and also the most downstream station within 

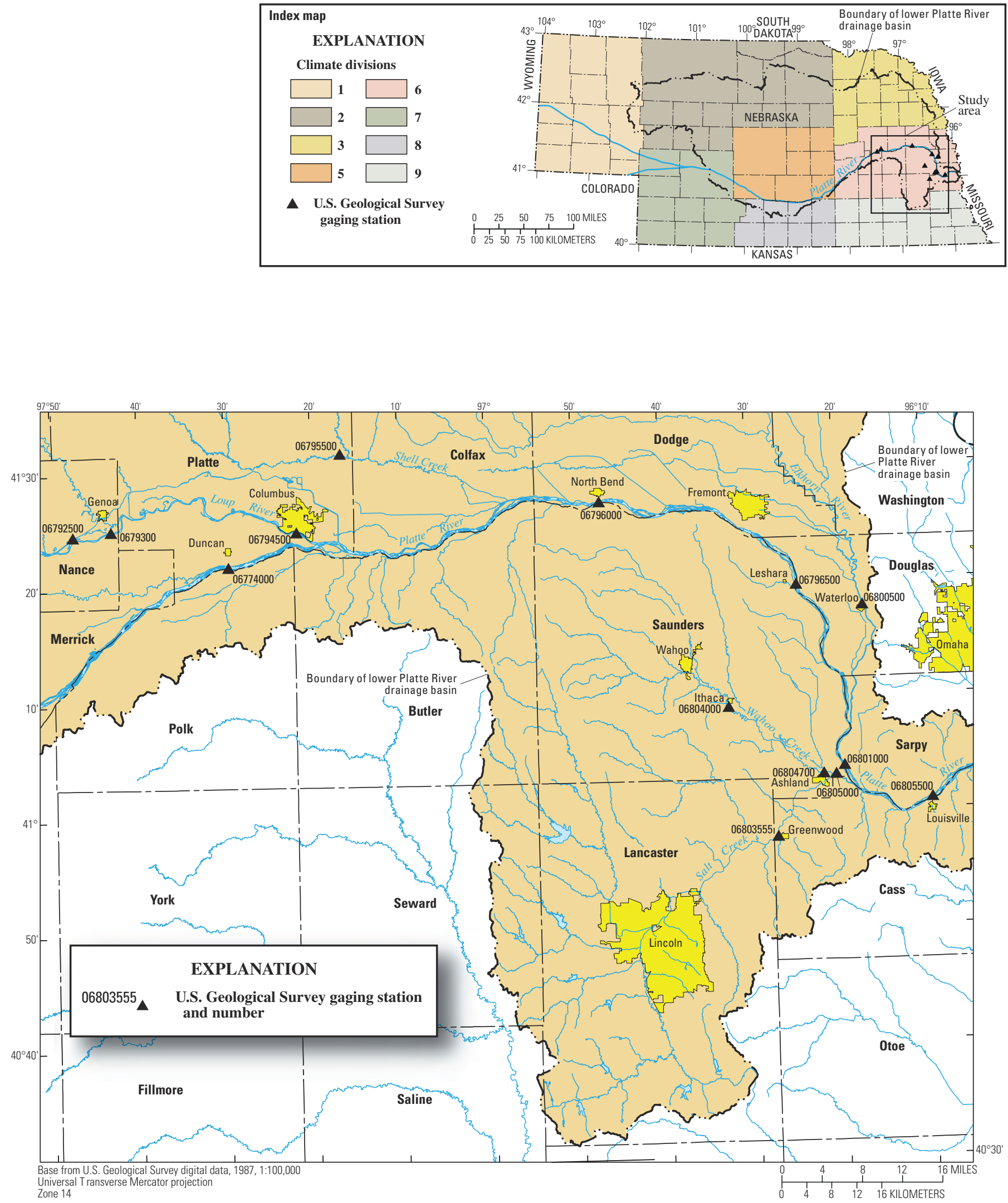

Horizontal coordinate information is referenced to the North American Datum of 1983 (NAD 83)

Figure 1. Location of study area and gaging stations on the Platte River and contributing tributaries, Nebraska. 
the central Platte River segment that flowed to the confluence with the Loup River where streamflow was seasonally gaged for more than 10 water years from 1895 to 2006 . That downstream station on the central Platte River was near Columbus, Nebraska, during the early part of the study period, but in 1928 was relocated to its current site (2006) near Duncan, Nebraska. The six discrete time periods selected for the study corresponded to the dates selected for companion studies within the larger CIS that were dependent upon detailed mapping efforts based on available aerial photography collections or detailed historical maps.

\section{Data and Methodology}

Daily streamflow for the lower Platte River main stem and major tributaries (fig. 1) and monthly climatic data from 1895 through 2006 were divided into six discrete 11-wateryear periods: 1895-1905, 1934-44, 1951-61, 1966-76, 198595, and 1996-2006. Gaging stations of interest on the Platte River main stem and tributaries are listed in tables 1 and 2.

\section{Streamflow Data}

Data (table 1) indicate three possible levels of record availability at each station and period: complete, partial, or no record. The term "partial" refers to unavailable discharge data (record gap) for part of the period. The term "no record" refers to unavailable discharge data for the entire period. Estimated data use records from one or more stations (index stations) to fill the record gap at other gaging station(s). Index stations are station(s) on the Platte River or contributing tributaries (table 2) that have complete records for the period of the record gap.

\section{Period 1895-1905}

Daily streamflow data for the period 1895-1905 were located in USGS reports (Stevens, 1909; U.S. Geological Survey, 1958) and transferred into electronic format for analysis. Daily streamflow data in this period were sparse and available only for the Duncan station on the Platte River main stem and for two tributaries-Loup River and Elkhorn River. Daily streamflows at the North Bend station were estimated as the sum of concurrent daily streamflows of two stations - the Platte River near Duncan and the Loup River at Columbus. Daily streamflows of the lower Platte River near Ashland were estimated as the sum of concurrent streamflows at the three stations-Platte River near Duncan, Loup River at Columbus, and Elkhorn River at Waterloo. Because daily streamflow data for other contributing tributaries were not available, daily streamflow at the North Bend and Ashland stations were probably underestimated for this period. Because no streamflow records for this period were known for tributaries downstream from the Elkhorn River, no estimation of daily streamflow was made for Platte River stations near Leshara and at Louisville. Because of sparse concurrent streamflow data among stations along the main stem and tributaries, no estimation of daily streamflow by linear regression or numerical modeling was attempted for this period.

\section{Period 1934-2006}

Daily streamflow records at five gaging stations on the Platte River were acquired from the National Water Information System (U.S. Geological Survey, 2007) for these periods: 1934-44, 1951-61, 1966-76, 1985-95, and 1996-2006. Estimated data were required to fill the record gap at gaging stations for periods with a "partial" or "no record" availability in table 1.

\section{Estimation of Missing Daily Streamflow Data}

Two estimation techniques were applied for missing daily streamflow data, depending on record availability of the index stations. The first technique was based on routing streamflow from upstream stations with DAFLOW (Jobson, 1989), a physically based numerical model. The second technique was based on a statistical approach. Using either technique, a quality assurance standard of data estimation was set to meet a preset condition. The condition was that for each 11-year period, the mean of estimated monthly streamflow of a station is not less than 100 cubic feet per second $\left(\mathrm{ft}^{3} / \mathrm{s}\right)$ of the mean monthly flow at the next upstream station and not more than $100 \mathrm{ft}^{3} / \mathrm{s}$ of the mean monthly flow of the next downstream station.

\section{DAFLOW Simulation}

Physically based routing is useful to predict streamflow for stations when no data are available from two or more consecutive stations within the same period. Discharges at one or more stations on the main-stem channel can be estimated simultaneously. Because DAFLOW is a routing model, the index stations have to be located upstream from the station(s) to be estimated. Streamflow data available at other downstream station(s) for the same period of interest are used to calibrate and validate the model.

Because contributions of ground-water flow and other ungaged areas are not considered in DAFLOW, the model often underestimated the streamflow at downstream stations and did not meet the requirement of quality assurance for estimated values. Therefore, the DAFLOW modeling technique was used only for the two consecutive stations, North Bend and Leshara, that had no available record in the 1934-44 period because simulation estimates were better than those from the statistical approach. A second technique was applied for the other periods and stations, by using a combination of linear regression and routing factors, referred to as the "statistical approach." 


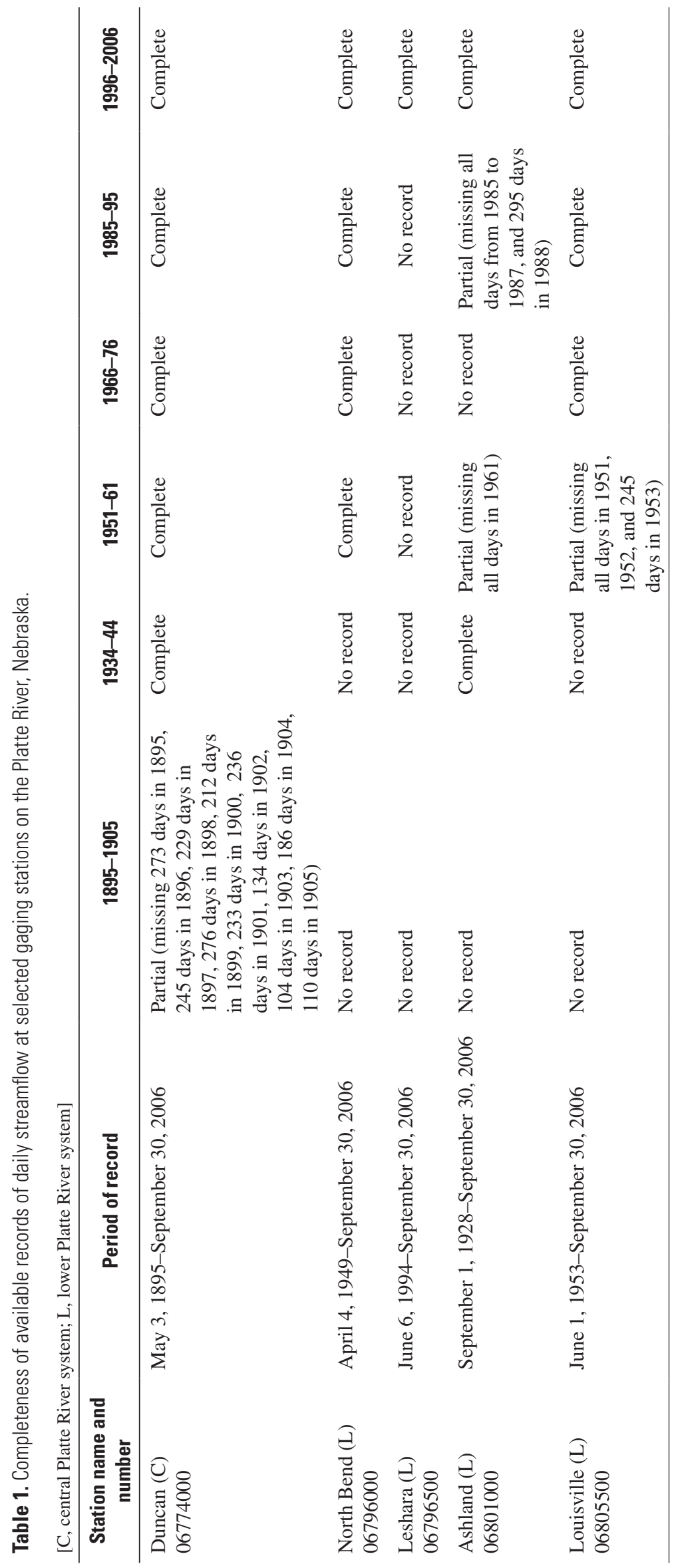




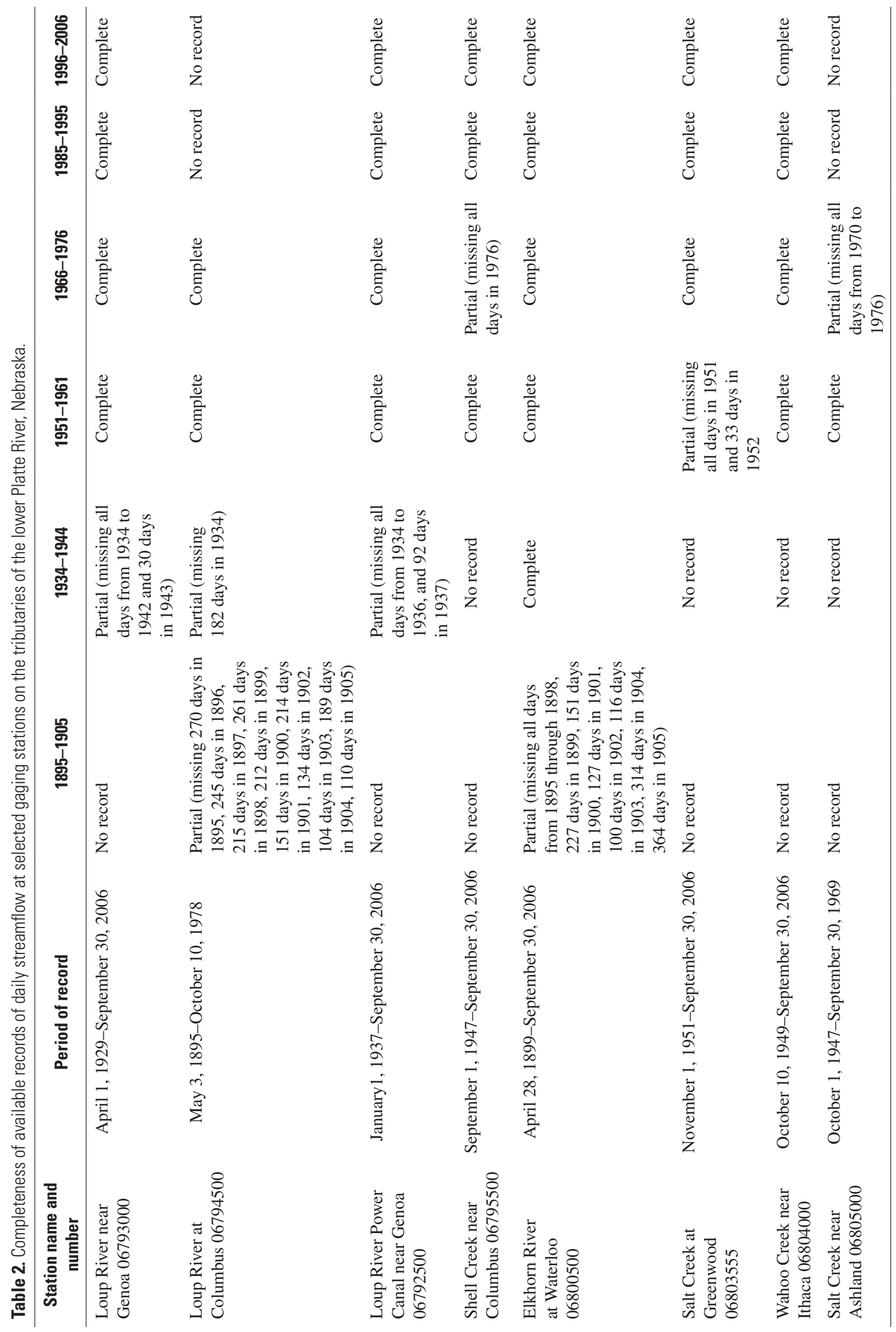




\section{Statistical Approach}

The statistical approach required a specific statistical model for each station and period of interest. Also the index stations used were the next stations upstream or next downstream from the station to be estimated, assuming that the closest location likely provided relatively similar physical settings and the least stream travel time between the stations.

A linear relation in streamflow between the index station(s) and the station to be predicted was assumed in the statistical approach. Because streamflow data were highly skewed, the linear relation was developed using a logarithmic transformation. The simple routing component embedded in the statistical technique assumed a time lag between index stations and stations to be estimated, depending on the distance and streamflow. Because streamflow velocity was not known, the time lag was assumed to be represented by weighting factors. For example, streamflow of Platte River at Louisville station (to be estimated) was the sum of flow of Platte River at Ashland and two tributaries, Wahoo Creek near Ithaca and Salt Creek at Greenwood (fig. 1). The relation was represented as:

$$
\begin{gathered}
\mathrm{Q}_{\mathrm{Lou}}(\mathrm{t})=\left[\mathrm{a}^{*} \mathrm{Q}_{\text {Ash }}(\mathrm{t}-1)+\mathrm{b} * \mathrm{Q}_{\text {Ash }}(\mathrm{t})\right]+\left[\mathrm{c}^{*} \mathrm{Q}_{\mathrm{Ith}}(\mathrm{t}-1)+\mathrm{d} * \mathrm{Q}_{\mathrm{Ith}}(\mathrm{t})\right]+ \\
{\left[\mathrm{e}^{*} \mathrm{Q}_{\mathrm{Gw}}(\mathrm{t}-1)+\mathrm{f}^{*} \mathrm{Q}_{\mathrm{Gw}}(\mathrm{t})\right],}
\end{gathered}
$$

where $\mathrm{Q}$ was daily mean flow $\left(\mathrm{ft}^{3} / \mathrm{s}\right)$ and $(\mathrm{t})$ was day $\mathrm{t}$. Lou, Ash, Ith, and $\mathrm{Gw}$ were gaging stations at or near Louisville, Ashland, Ithaca, and Greenwood, respectively. Ground-water inflow was unknown, but that quantity was included implicitly within the regression parameters. The $\mathrm{a}, \mathrm{b}, \mathrm{c}, \mathrm{d}, \mathrm{e}$, and $\mathrm{f}$ were time-lag weighted coefficients, where $\mathrm{a}+\mathrm{b}=1, \mathrm{c}+\mathrm{d}=1$, and $\mathrm{e}+\mathrm{f}=1$. Although $\mathrm{a}, \mathrm{b}, \mathrm{c}, \mathrm{d}, \mathrm{e}$, and $\mathrm{f}$ were unknown, the values were derived iteratively to maximize the coefficient of determination $\left(\mathrm{R}^{2}\right)$ of a linear regression.

The simple linear regression was constructed using the concurrent records between index station(s) and the station to be predicted. As for the example case given (Louisville), concurrent data were used to fit with the regression model:

$$
\log (\mathrm{Y})=\mathrm{A} * \log (\mathrm{X}),
$$

where $\mathrm{Y}$ is $\mathrm{Q}_{\mathrm{Lou}}(\mathrm{t})+1$, and

$$
\begin{gathered}
\mathrm{X}=\left[\mathrm{a}^{*} \mathrm{Q}_{\mathrm{Ash}}(\mathrm{t}-1)+\mathrm{b}^{*} \mathrm{Q}_{\mathrm{Ash}}(\mathrm{t})\right]+\left[\mathrm{c}^{*} \mathrm{Q}_{\mathrm{Itt}}(\mathrm{t}-1)+\mathrm{d} * \mathrm{Q}_{\mathrm{Ith}}(\mathrm{t})\right]+ \\
{\left[\mathrm{e}^{*} \mathrm{Q}_{\mathrm{Gw}}(\mathrm{t}-1)+\mathrm{f}^{*} \mathrm{Q}_{\mathrm{Gw}}(\mathrm{t})\right]+1 .}
\end{gathered}
$$

Clearly $\mathrm{Y}$ and $\mathrm{X}$ had to be larger than zero, so the constant was added to each equation to prevent logarithm of a zero streamflow. Estimates of missing daily streamflow for a station were computed by entering known concurrent daily streamflow for the index stations. Because the regression equations were fit using log-transformed values, predicted streamflow estimates were derived by exponentiating the model-predicted values back into the original units and subtracting the constant.

\section{Climate Data and Association with Streamflow Gages}

Platte River basins draining to the main-stem gages were located within four Nebraska climate divisions, that is, divisions 2, 3, 5, and 6 (fig. 1). North Bend gaging station measured streamflow originating from the central Platte and from the Loup Rivers and Shell Creek, which were within Nebraska climate divisions 2 and 5. Leshara gaging station measured streamflow from basins within climate divisions 2, 5, and 6 . Ashland and Louisville gaging stations measured streamflow from basins within climate divisions 2, 3, 5, and 6 .

Monthly precipitation and Palmer Hydrological Drought Index (PHDI) data for climate divisions were obtained from the National Climatic Data Center (National Climatic Data Center, 2007). The PHDI indicated the severity of a dry or wet spell, and is based on the principles of a balance between moisture supply and demand to assess long-term moisture supply. The index generally ranged from -6 to +6 , with negative values indicating dry spells, and positive values indicating wet spells. The PHDI was classified (National Climatic Data Center, 2007) as follows: 0 to $-0.5=$ normal; -0.5 to $-1.0=$ incipient drought; -1.0 to $-2.0=$ mild drought; -2.0 to $-3.0=$ moderate drought; -3.0 to $-4.0=$ severe drought; and less than $-4.0=$ extreme drought. These adjectives also were attached to corresponding ranges of positive values for wet spells. Manmade changes such as increased irrigation, new reservoirs, and added industrial water use were not considered by the National Climatic Data Center in the computation of the PHDI.

\section{Selection of Nonredundant Hydrologic Indices}

Daily-mean and annual-peak streamflow data for each station-period combination were formatted to meet the input requirement of the Hydroecological Integrity Assessment Process (HIP) software (Henriksen and others, 2006). A total of 171 HIs were calculated with the HIP software for each station-period combination, except for the 1895-1905 period because of sparse streamflow data.

To aid in description, the 171 indices were grouped into five major categories following Richter and others (1996) and Poff and others (1997). The major categories were indices of magnitude, frequency, duration, timing, and rate of change. Magnitude indices were subsequently divided into three types of streamflow conditions - average, low, and high. Frequency and duration indices were subsequently divided into low- and high-flow conditions. This classification produced a total of nine subcategories of hydrologic indices that described different facets of the streamflow regime. Each hydrologic index had a definition and alphanumeric code (table 3 ). The first letter of the alphanumeric code referred to the first letter of the major category of the streamflow regime ( $M$, magnitude; 
$F$, frequency; $D$, duration; $T$, timing; $R$, rate of change). The second letter of the alphanumeric code referred to the types of flow condition ( $A$, average; $L$, low; $H$, high). Indices were numbered successively within each category. For example, MA12 and MA23 were the 12th and the 23th indices within the magnitude category of average streamflow condition for January and December, respectively; ML1 and ML12 were the first and the 12th indices within the magnitude category of low-flow condition for January and December, respectively; the MH1 and MH12 were the first and the 12th indices within the magnitude category of the high-flow condition for January and December, respectively (table 3).

The calculated values of the 171 HIs for all stationperiod combinations were then combined into a single file in a format suitable for selection of nonredundant indices using the PRINCOMP procedure of SAS (SAS Institute Inc., 1989). The PRINCOMP procedure performed the principal component analysis (PCA) on the correlation matrix of the 171 HIs. Contribution of variance (eigenvalues) among the principal components was used to determine significant principal components. Analysis indicated that the first four principal components (I, II, III, and IV) explained 90 percent of the total variance. Groups of indices that exhibit the largest absolute loadings (eigenvectors) on the four principal component axes were identified as described in detail by Olden and Poff (2003). In brief, the selection of HIs for each of the nine subcategories of the streamflow regime was based on the largest absolute loading in each significant principal component. For example in this study, the PCA resulted in four principal components that described most of the variability. Because there are four significant principal components, four indices were selected for each of the nine subcategories of the flow regime. Each selected index had the largest loading on one principal component among all the indices within the same subcategory. The selection process would result in a maximum of 36 indices, which were relatively independent of each other and so-called nonredundant indices.

Several additional indices of streamflow magnitude that add clarity to the interpretation of nonredundant indices were computed using the UNIVARIATE procedure of SAS (SAS Institute Inc., 1989) and added to the selected set. These are the median of the monthly mean, maximum, minimum, skewness and coefficient of variation of streamflow. Definitions for the monthly streamflow indices are listed in table 3.

Because daily streamflow records were sparse in the 1895-1905 period, only the monthly streamflow indices were computed using the UNIVARIATE procedure of SAS (SAS Institute Inc., 1989). Only the months that had 15 or more daily streamflow values were eligible for calculation of monthly mean flow. A minimum of 3 years of each eligible month was required for the calculation of the monthly streamflow indices. Because of these two data restrictions, HIs of monthly streamflow magnitude were not available for certain months for the 1895-1905 period. No nonredundant hydrologic indices were computed for this period because insufficient data were available for use of the HIP software.

\section{Statistical Analysis and Tests}

Monthly streamflow indices and nonredundant HIs were compared among targeted periods using statistical tests to determine the significance of differences among those periods for each streamflow-gaging station. Existence of significant differences among periods may indicate occurrence and the period of occurrence of natural and/or anthropogenic alterations of the streamflow regime. The data flow from data preparation through temporal comparison among the 11-water-year periods is summarized in fig. 2 .

\section{Two-Sided Nonparametric Prediction Interval for Indices}

Nonparametric prediction interval (PI) with confidence level alpha $(\alpha)$ is simply the interval between the $\alpha / 2$ and 1$\alpha / 2$ percentiles of the distribution (Helsel and Hirsch, 1992), that is

$$
P I=X_{\alpha / 2 \bullet(n+1)} \quad \text { to } \quad X_{[1-(\alpha / 2)] \bullet(n+1)}
$$

where $\mathrm{n}$ was number of observations. The PI is bounded by the values of the observations with ranks of $\alpha / 2 \bullet n$ and $(1-\alpha / 2) \bullet n$, respectively. When the rank was not an integer, then the value of the rank was interpolated from the values of the two nearest integer ranks. Each 11-water-year period in this study contains 11 annual values for summary by each monthly or nonredundant index, which resulted in $\mathrm{n}=11$ for most indices. The small size of $n=11$ was only sufficient to allow reliable percentile computations for the 25th and 75th percentiles or $\alpha=0.50$. Following Jordan (1991), the minimum number of $n=10$ was required for the 25th, 50th, and 75th percentile computations.

\section{Comparison of Nonredundant Hydrologic Indices}

Because the HIP software reported the 25th and 75th percentiles of most of the indices but did not report the values (usually annual) from which the percentiles were derived, conclusive nonparametric statistical tests of differences among periods could not be attempted. Instead, only qualitative comparisons based on the lower- and upper-interquartile values are reported. Interquartile ranges of an index that overlapped for two station-period combinations were assumed to have come from the same distribution, and conversely. Therefore, if the two interquartile ranges did not overlap, the two periods potentially differed.

The HIP software did not or could not compute the quartile values for some of the nonredundant indices (for example because of lack of peak-flow data) and thus interquartile-range comparison was not possible. For these indices, qualitative comparisons among the time periods at a station sometimes 
Table 3. Definition and alphanumeric code of the monthly streamflow indices and the nonredundant hydrologic indices for the Platte River from Duncan through Louisville, Nebraska (modified from Henriksen and others, 2006).

$\left[\mathrm{ft}^{3} / \mathrm{s}\right.$, cubic feet per second]

Code

MA12 to MA23

MA24 to MA35

ML1 to ML12

MH1 to MH12

MA43

ML13

ML20

ML18

MH26

FL2

FL3

FH2

\section{Definition}

Median of monthly mean streamflow for each month. Using the daily mean streamflow, monthly mean streamflow was computed for each month in each year in the period. The median of monthly mean streamflow was the 50th percentile of the monthly mean streamflow values for each month across all years in the period. For example, the MA12 for the 1934-44 period was the median of 11 monthly mean streamflow values for January in the period.

Median of variability of monthly streamflow for each month. The standard deviation, the mean, and the coefficient of variation ( $\mathrm{CV}=$ standard deviation divided by the mean) was computed for each month in each year in the period. The median of variability of monthly streamflow values was the 50th percentile of monthly CV values for each month across all years in the period. For example, the MA24 for the 1934-44 period was the median of 11 monthly $\mathrm{CV}$ values for January in the period.

Median of monthly minimum streamflow for each month. Using the daily mean streamflow, the monthly minimum streamflow was computed for each month in each year in the period. The median of minimum streamflow for each month was the 50th percentile of the monthly minimum values across all years in the period. For example, the ML1 for the 1934-44 period was the median of 11 minimum-streamflow values for January in the period.

Median of monthly maximum streamflow for each month. Using the daily mean streamflow, the monthly maximum streamflow was computed for each month in each year in the period. The median of maximum streamflow for each month was the 50th percentile of monthly maximum values across all years in the period. For example, the MH1 for the 1934-44 period was the median of 11 maximum-streamflow values for January in the period.

Variability across annual discharge. The MA43 was derived by computing the first (25th percentile) and third (75th percentile) quartiles for the 11 annual-mean streamflow (every year in the period). The MA43 was the third quartile minus the first quartile divided by the median of the 11 annual-mean streamflow (dimensionless).

Variability across monthly minimum streamflow values. The ML13 was derived by computing the mean and standard deviation for the monthly minimum streamflow in the period. The ML13 was the standard deviation times 100 divided by the mean of monthly minimum streamflow for all years in the period (percent).

Ratio of total discharge and base streamflow. The ML20 was derived by dividing the daily streamflow record into 5-day blocks, finding the minimum streamflow for each block, and assigning the minimum streamflow as a base streamflow for that block if 90 percent of that minimum streamflow was less than the minimum streamflow for the blocks on either side; otherwise, it was set to zero, and the zero values were filled using linear interpolation. Then, the total streamflow and the total base streamflow for the entire record were calculated. The ML20 was the ratio of total streamflow to total base streamflow (dimensionless).

Variability in base streamflow. The ML18 was derived by computing the standard deviation for the ratios of 7-day moving average streamflow to mean annual streamflow for each year. The ML18 was the standard deviation times 100 divided by the mean of the ratios (percent).

High peak streamflow ratio. The MH26 was derived by computing the average peak streamflow value for streamflow events above a threshold equal to seven times the median streamflow for the entire record in the period. The MH26 was the average peak streamflow divided by the median streamflow for the entire record in period (dimensionless).

Variability in low-flood pulse count. The FL2 was derived by computing the standard deviation in the annual counts for low-flood pulses (FL1). The FL2 was 100 times the standard deviation divided by the mean low-flood pulse counts (percent). The low-flood pulse count, FL1, was derived by computing the average number of streamflow events with streamflow below a threshold equal to the 25 th percentile value for the entire streamflow record in the period. The FL1 was the average number of events per year.

Frequency of low pulse spells. The FL3 was derived by computing the average number of streamflow events with streamflow below a threshold equal to 5 percent of the median streamflow value for the entire streamflow record in the period. The FL3 was the average number of events per year.

Variability in high-streamflow pulse count. The FH2 was derived by computing the standard deviation in high-flood pulse count FH1. The FH2 was 100 times the standard deviation divided by the mean pulse count (number of events per year). The FH1 was derived by computing the average number of streamflow events with streamflow above a threshold equal to the 75th percentile value for the entire streamflow record in period.

Flood frequency using a threshold equal to seven times the median streamflow. The FH7 was derived by computing the average number of streamflow events with streamflow above a threshold equal to seven times the median streamflow value for the entire streamflow record in period. The FH7 was the average number of events per year. 
Table 3. Definition and alphanumeric code of the monthly streamflow indices and the nonredundant hydrologic indices for the Platte River from Duncan through Louisville, Nebraska (modified from Henriksen and others, 2006).-Continued

$\left[\mathrm{ft}^{3} / \mathrm{s}\right.$, cubic feet per second]

\begin{tabular}{cc}
{$\left[\mathrm{ft}^{3} / \mathrm{s}\right.$, cubic feet per second $]$} & Definition \\
\hline Code &
\end{tabular}

FH8 Flood frequency using a threshold equal to 25-percent exceedence. The FH8 was derived by computing the average number of streamflow events with streamflow above a threshold equal to 25-percent exceedence value for the entire streamflow record in the period. The FH8 was the average number of events per year.

Annual minimum daily streamflow. The DL1 was derived by computing the minimum 1-day average streamflow for each year. The DL1 was the mean of these values $\left(\mathrm{ft}^{3} / \mathrm{s}\right)$.

DL14

Low exeedence streamflow. The DL14 was derived by computing the 75-percent exeedence value for the entire streamflow record in the period. The DL14 was the exceedence value divided by the median for the entire record in the period (dimensionless).

DL17 Variability in low-streamflow pulse duration. The DL17 was derived by computing the standard deviation for the yearly average of low-streamflow pulse durations. The DL17 was 100 times the standard deviation divided by the mean of the yearly average low-streamflow pulse durations (percent).

DL19 Variability in the number of zero-streamflow days. The DL19 was derived by computing the standard deviation for the annual number of zero-streamflow days. The DL19 was 100 times the standard deviation divided by the mean annual number of zero-streamflow days (percent).

DH1

Annual maximum of daily streamflow. The DH1 was derived by computing the maximum of a 1-day moving average streamflow for each year. The DH1 was the mean of these values $\left(\mathrm{ft}^{3} / \mathrm{s}\right)$ for the period.

$\mathrm{DH} 2$

Annual maximum of 3-day moving-average streamflow. The DH2 was derived by computing the maximum of a 3-day moving-average streamflow for each year. The DH2 was the mean of these values $\left(\mathrm{ft}^{3} / \mathrm{s}\right)$.

DH6 Variability of annual maximum of 1-day moving-average streamflow. The DH6 was derived by computing the standard deviation for the maximum 1-day moving averages. The DH6 was 100 times the standard deviation divided by the mean (percent).

DH7

Variability of annual maximum of 3-day moving-average streamflow. The DH7 was derived by computing the standard deviation for the maximum 3-day moving averages. The DH7 was 100 times the standard deviation divided by the mean (percent).

DH14

Flood duration. The DH14 was derived by computing the mean of the mean monthly streamflow values and finding the 95th percentile for the mean monthly streamflow. The DH14 was the 95th percentile value divided by the mean of the mean monthly (dimensionless).

TA3 Seasonal predictability of flooding. The TA3 was derived by dividing the water year into 2-month periods (that was, October-November, December-January, and so forth) and counting the number of flood days (streamflow events with streamflow greater than 1.67-year flood) over the entire streamflow record in the period. The TA3 was the maximum number of flood days in any one period divided by the total number of flood days.

TL4

Seasonal predictability of non-low streamflow. The TL4 was derived by computing the number of days that streamflow was above the 5-year flood threshold, expressed as the ratio of the number of days to 365 or 366 (leap year) for each year. The TL4 was the maximum of the yearly ratios (dimensionless).

TH3

RA1

Seasonal predictability of non-flooding. The TH3 was computed as the maximum proportion of a 365-day year that the streamflow was less than the 1.67-year flood threshold and also occurs in all years. Non-flood days that span all years were then accumulated. TH3 was maximum length of those flood-free periods divided by 365 (dimensionless).

Rise rate. The RA1 was derived by computing the change in streamflow for days in which the change was positive for the entire streamflow record in the period. The positive change occurred when the streamflow at day $n$ was lower than the streamflow at day $n+1$. The RA1 was the mean of these values $\left(\mathrm{ft}^{3} / \mathrm{s}\right.$ per day).

RA2 Variability of rise rate. The RA2 was derived by computing the standard deviation for the positive streamflow changes. The RA2 was 100 times the standard deviation divided by the mean (percent).

RA3 Fall rate. The RA3 was derived by computing the change in streamflow for days in which the change was negative for the entire streamflow record in the period. The negative change at day $n$ occurred when the streamflow at day $n$ was larger than the streamflow at day $n+1$. The RA3 was the mean of these values $\left(\mathrm{ft}^{3} / \mathrm{s}\right.$ per day).

RA4

Variability in fall rate. The RA4 was derived by computing the standard deviation for the negative streamflow changes. The RA4 was 100 times the standard deviation divided by the mean (percent).

RA8

Number of fluctuations. Streamflow fluctuation was the number of days in each year when the streamflow fluctuated from one day to the next. Fluctuation in streamflow for day $n$ occurred if the streamflow on day $n$ was greater or lower than the streamflow at the previous day (day $n-1)$ and next day (day $n+1)$. The RA8 was derived by computing the number of days in each year for period, when the streamflow fluctuated (days per year). 
National Water Information System (NWIS) records Estimation of Missing Daily Streamflow Record with DAFLOW Simulation or Statistical approach

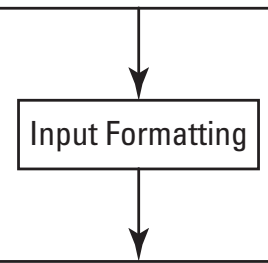

Hydroecological Integrity Assessment Process (HIP) Software (generating 171 hydrologic indices)

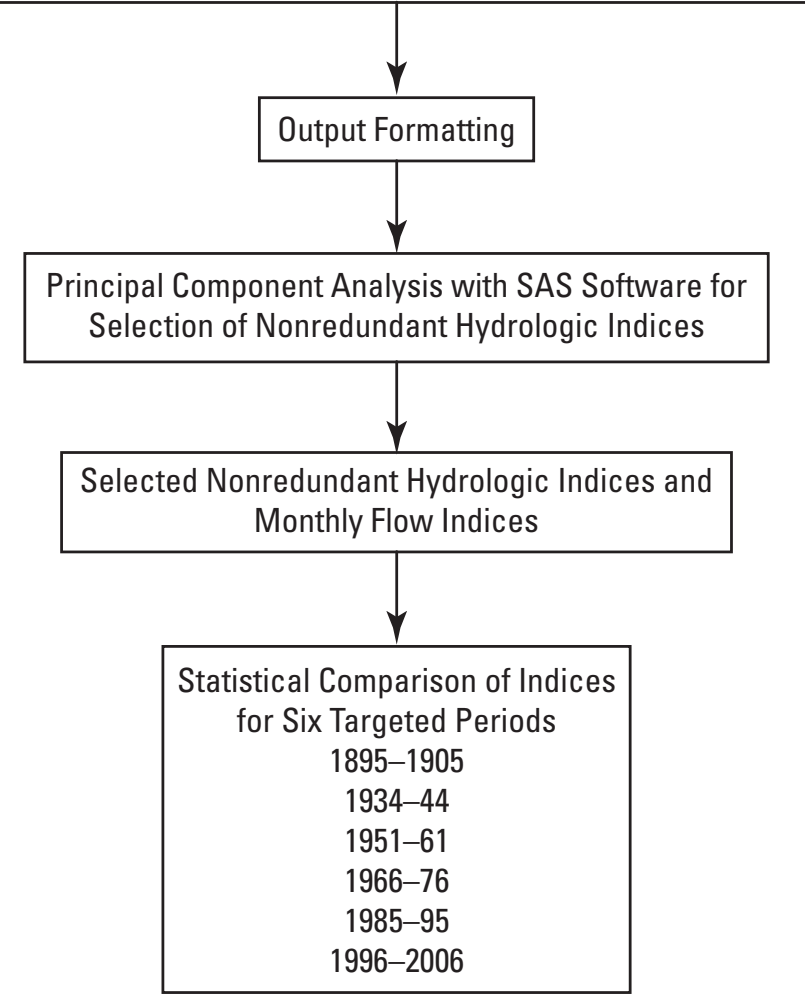

Figure 2. Sequence of data analysis for hydrologic indices.

were attempted because of the consistency of differences with those for all other stations.

\section{Nonparametric Statistical Comparison of Monthly Climate and Monthly Streamflow}

Comparisons among periods in monthly climate and monthly streamflow for each station, were made with nonparametric methods using the analysis of variance (ANOVA) approximation of the Kruskal-Wallis test (Helsel and Hirsch, 1992). A one-way ANOVA applied to the ranks of the response variable is equivalent to the Kruskal-Wallis k-sample test. $F$-test statistic generated by the parametric procedure applied to the ranks was often more robust than the Chi square approximation used by Kruskal-Wallis (SAS Institute
Inc., 1990). The ranks of monthly streamflow and climate variables for each station-month combination were obtained using RANK procedure of SAS. The one-way ANOVA on the ranks for each station used the GLM procedure of SAS (SAS Institute, 1990) and the Duncan's multiple-range test (Duncan, 1955) was used to indicate significant differences of one time period from the others. Significant differences among periods were declared using a 95-percent confidence level, alpha $=0.05 ; p$-value less than alpha indicated that at least one period was significantly different from the other periods.

\section{Association of Monthly Climate and Streamflow}

The degree of association between monthly climate and streamflow for each station-month combination was determined using the Kendall's tau (Kendall and Gibbons, 1990). Tau, a rank-based correlation procedure, measures the strength of monotonic relation between two variables (Helsel and Hirsch, 1992). Kendall's tau was calculated using the CORR procedure (SAS Institute Inc., 1989). Significant correlation was declared when $p$-value was less than alpha $=0.05$.

\section{Temporal Differences in Climate and Hydrologic Indices}

Median values and statistical test results for temporal differences in monthly climate and monthly streamflow indices, and potential temporal differences in nonredundant HIs are discussed. Lower and upper quartile values of the monthly climate and monthly streamflow indices are presented in Appendix 1 to 7.

\section{Temporal Differences in Climate and Association with Monthly Streamflow}

Temporal differences among the periods in monthly precipitation varied consistently with month and climate-division combinations. Monthly precipitation from January through June and from September through November in all climatic divisions was not significantly different among the 11-wateryear periods (table 4 ).

The lower Platte River basin was under a widespread drought (moderate to severe) during the 1934-1944 period; the median of monthly PHDI was uniformly $<-2$ (table 5) except -1.93 for February in climate division 3. The widespread drought was preceded by a widespread wet period (mildly to moderately wet) during the 1895-1905 period, followed by an incipient drought to incipiently wet period (1951-61) and an incipient drought to mildly wet period (1966-76), another widespread wet condition (moderately wet) during the 1985-95 period, and an incipient drought to mildly wet period (1996-2006). Note that climate conditions in all climate 


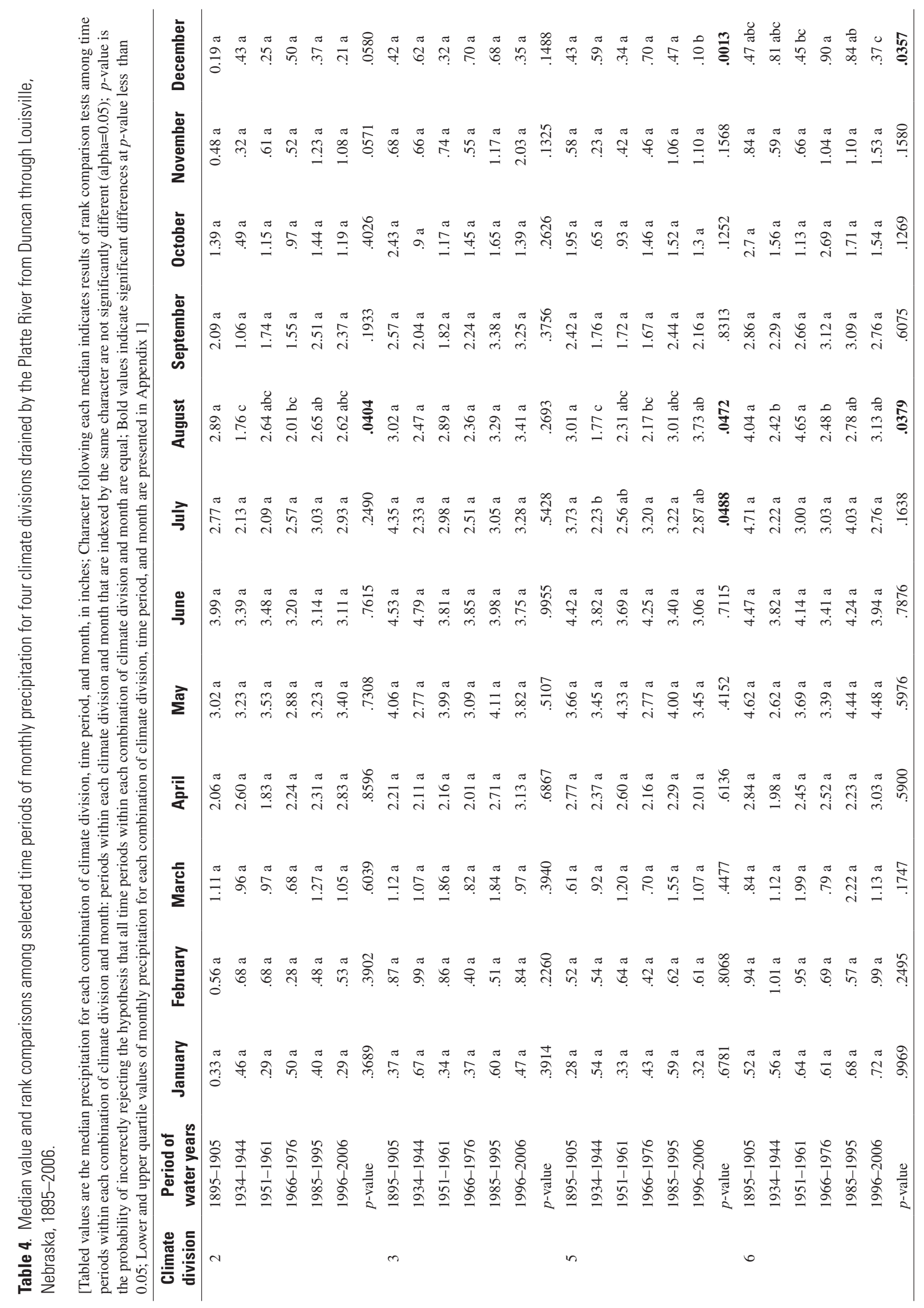


divisions during the 1951-61 (except climate division 6) and 1996-2006 periods (except climate division 3) were mixed type; that is, monthly drought and wet conditions occurred within each period. The monthly climate conditions during the 1966-76 period were wet (incipiently to mildly wet), except for the mixed-type climate conditions in climate division 2.

Temporal differences in the monthly PHDI varied among the month and climate division combinations. For instance, median PHDI values for climate divisions 2 and 3 during 1951-61 were consistently less (drier) than those during 1996-2006 (with the exception of May in climate division 3). But for climate division 6, the situation was reversed: median PHDI values were negative (except for July) and uniformly less (drier) during 1996-2006 than during 1951-61. Also during the 1951-61 period, drought was not the average climatic condition for the entire lower Platte River basin because none of the medians of the monthly PHDI values were negative for climate division 6.

Kendall's tau values indicated a positive correlation between monthly streamflow and monthly PHDI. Rank correlations of monthly streamflow and monthly PHDI were stronger than those of streamflow and monthly precipitation (table 6). Correlations of monthly streamflow with monthly PHDI were significant for all months and stations; whereas, correlations with precipitation were significant only from May through September for stations upstream from Louisville, and from April through November for the Louisville station.

\section{Temporal Differences in Monthly Streamflow Indices}

The rank comparisons of monthly mean (table 7) and monthly maximum streamflow (table 8 ) between the 18951905 and 1985-95 periods revealed the combined effects of streamflow regulation and other anthropogenic activities on streamflow magnitude. Although rank comparison was not significant (number of observations, $\mathrm{n}=11$, in each period limited the statistical power of comparison), median values of monthly PHDI were less during the 1895-1905 period than that during the 1985-95 period for all climate divisions (table 5). However, monthly streamflow at Duncan, North Bend, and Ashland stations (where concurrent monthly streamflow data were available for the two periods) were sometimes higher during the 1895-1905 period than those during the 1985-95 period. April streamflow was higher in the 1895-1905 period for Duncan and North Bend stations (tables 7 and 8) than in the 1985-95 period; for Duncan, North Bend, and Ashland stations from May to July [typically wet months and historically the months when mountain snowmelt would course through the lower Platte (Wohl, 2001)], streamflow was the highest in the 1895-1905 period, the period prior to building of most major storage reservoirs (Eschner and others, 1983) and many other water management projects in the Platte River basin. The temporal difference confirms that monthly mean and monthly maximum streamflow were higher prior to building of major storage reservoirs. However, during the post-snowmelt months from August through November, the monthly mean and monthly maximum streamflow in the 1895-1905 period were either less than or more similar to those in the 1985-95 period. This contrast of monthly streamflow between wet and dry months indicated wider amplitude of monthly streamflow in the period prior to building major storage reservoirs. Streamflow amplitude was defined as the difference between the highest and lowest median values of monthly mean streamflow. The effects of major reservoirs on monthly minimum streamflow (table 9 ) were less obvious. For all three stations and months compared, except May and June, the monthly minimum streamflow in the $1895-1905$ period was similar to or less than the monthly minimum streamflow in the 1985-1995 period.

Among the other five periods from 1934 to 2006, periods when major reservoirs were operational on both North Platte River and South Platte River and streamflow was increasingly managed (for flood prevention, hydroelectricity, agriculture, residential and industrial consumption, recreation, aquatic habitats, and other purposes), the rank comparisons of monthly mean, maximum, and minimum streamflow (tables 7, 8, and 9) indicated the effects of varying climate conditions. When there were significant differences among the periods, the differences were mainly evident between the two periods of greatest contrast in climate conditions; the monthly streamflow in the 1934-44 moderate- to severe-drought period were significantly lower than those in the 1985-95 moderately wet period. When the contrast in climatic conditions between two periods was not very pronounced, generally the monthly streamflow between the two periods were similar. For example, most of the monthly streamflow for the moderately wet period (198595), the incipient drought to incipiently wet period (1951-61) and incipient drought to mildly wet period (1996-2006), and the mildly wet period (1966-76) did not significantly differ. Most of the monthly streamflow for the 1934-44, 1951-61, 1966-76, and 1996-2006 periods did not significantly differ.

The median of monthly skewness coefficients of streamflow from February to September at the Platte River mainstem stations were all positive values (table 10). The monthly skewness coefficients of streamflow for other months, were either positive or negative depending on the station-period combinations. Statistical ranking differences for coefficients of monthly skewness and coefficients of variation of streamflow were evident mainly for comparisons among time periods for the central Platte River system at Duncan station. Median values of monthly skewness coefficients of streamflow at Duncan station in either the 1934-44 or the 1951-61 periods were generally largest among the periods, except for May and June; the coefficients of skewness were generally smallest in the 1985-95 or 1996-2006 periods. Monthly skewness coefficients of streamflow at Duncan station in either the 1934-44 or 1951-61 periods differed significantly (for seven months) from one or more 11-water-year periods (table 10). Large coefficients of variation and skewness, and positive monthly values of skewness of streamflow from the central Platte River 


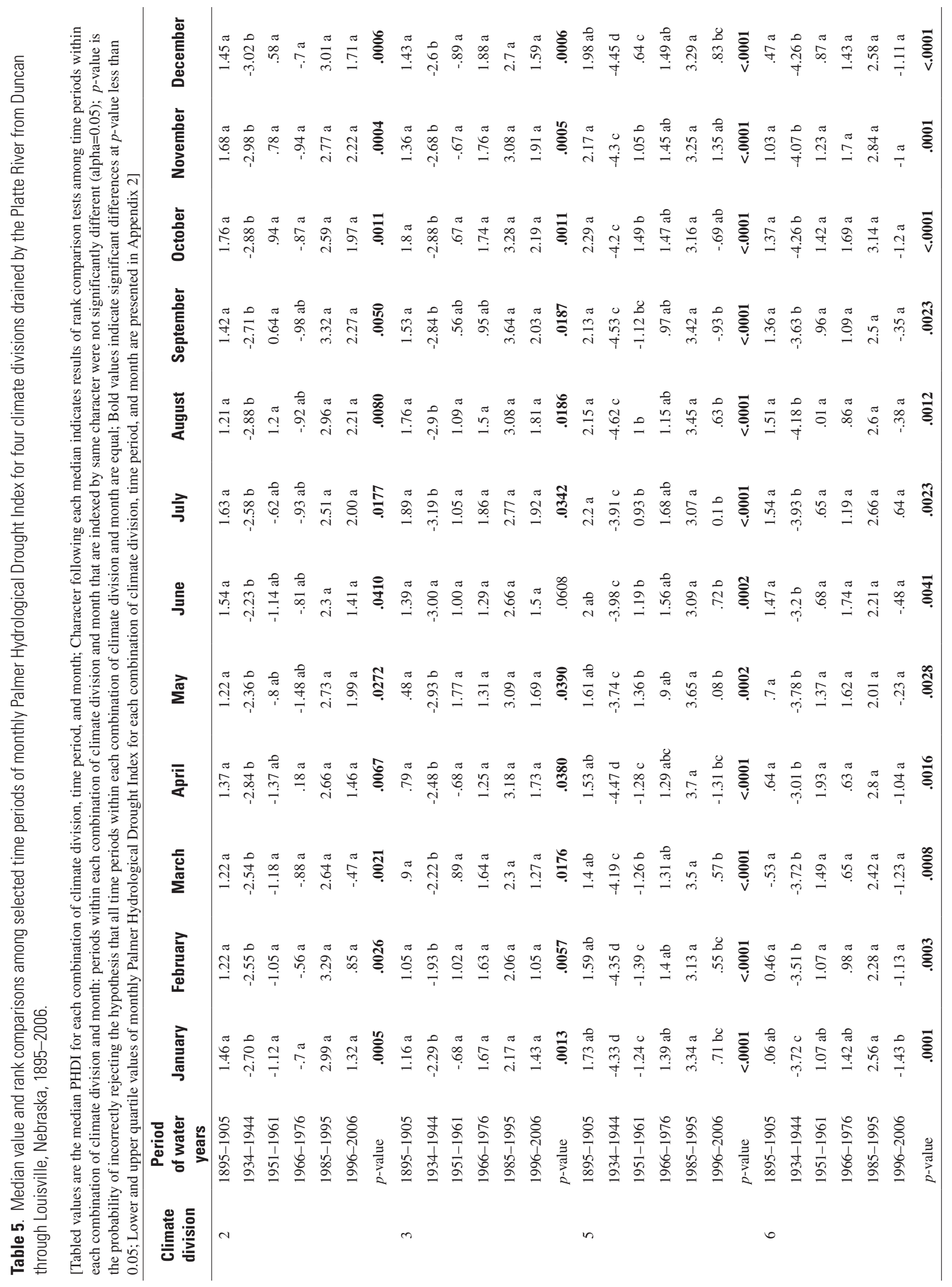


Table 6. Kendall's tau rank correlation of monthly streamflow with monthly precipitation and monthly Palmer Hydrological Drought Indices for four climatic divisions drained by the Platte River from Duncan through Louisville, Nebraska, 1895-2006.

[Div., climate division; only Kendall's tau values followed by *,**, and $* * *$ are significantly different from zero at $p$-value less than $0.05,0.01$, and 0.001 , respectively]

\begin{tabular}{|c|c|c|c|c|c|c|c|c|c|c|c|c|c|}
\hline \multirow{2}{*}{$\begin{array}{c}\text { Station } \\
\text { name }\end{array}$} & \multirow{2}{*}{ Div. } & \multicolumn{12}{|c|}{ Precipitation } \\
\hline & & January & February & March & April & May & June & July & August & September & October & November & December \\
\hline \multirow[t]{2}{*}{ Duncan } & 2 & -0.02 & -0.02 & -0.04 & 0.01 & $\begin{array}{r}0.30 \\
* * *\end{array}$ & $\begin{array}{c}0.19 \\
*\end{array}$ & $\begin{array}{c}0.31 \\
* * *\end{array}$ & $\begin{array}{c}0.19 \\
*\end{array}$ & $\begin{array}{r}0.30 \\
* * *\end{array}$ & $\begin{array}{c}0.18 \\
*\end{array}$ & 0.08 & 0.01 \\
\hline & 5 & -.11 & .03 & -.09 & .16 & $\begin{array}{l}.29 \\
* * *\end{array}$ & .16 & $\begin{array}{l}.32 \\
* * *\end{array}$ & $\begin{array}{l}.27 \\
* *\end{array}$ & $\begin{array}{l}.25 \\
* *\end{array}$ & .16 & .08 & .03 \\
\hline North Bend & 5 & -.09 & .05 & -.02 & $\begin{array}{l}.19 \\
*\end{array}$ & $\begin{array}{l}.40 \\
* * *\end{array}$ & $\begin{array}{l}.27 \\
* *\end{array}$ & $\begin{array}{l}.32 \\
* * *\end{array}$ & $\begin{array}{l}.33 \\
* * *\end{array}$ & $\begin{array}{l}.27 \\
* *\end{array}$ & .13 & .12 & -.01 \\
\hline Leshara & 2 & -.05 & .06 & -.06 & .04 & $\begin{array}{l}.28 \\
* *\end{array}$ & $\begin{array}{l}.24 \\
* *\end{array}$ & $\begin{array}{l}.29 \\
* *\end{array}$ & $\begin{array}{l}.22 \\
*\end{array}$ & $\begin{array}{l}.36 \\
* * *\end{array}$ & .17 & .10 & -.02 \\
\hline \multirow[t]{4}{*}{ Ashland } & 2 & .05 & .05 & -.09 & .11 & $\begin{array}{l}.20 \\
*\end{array}$ & $\begin{array}{l}.21 \\
*\end{array}$ & $\begin{array}{l}.31 \\
* * *\end{array}$ & $\begin{array}{l}.27 \\
* *\end{array}$ & $\begin{array}{l}.30 \\
* * *\end{array}$ & .14 & .11 & .02 \\
\hline & 3 & .06 & .07 & .02 & .13 & $\begin{array}{l}.35 \\
* * *\end{array}$ & $\begin{array}{l}.20 \\
*\end{array}$ & $\begin{array}{l}.30 \\
* * *\end{array}$ & $\begin{array}{l}.32 \\
* * *\end{array}$ & $\begin{array}{l}.27 \\
* *\end{array}$ & .14 & .05 & .03 \\
\hline & 5 & .01 & .04 & .04 & $\begin{array}{l}.18 \\
*\end{array}$ & $\begin{array}{l}.27 \\
* *\end{array}$ & .11 & $\begin{array}{l}.28 \\
* *\end{array}$ & $\begin{array}{l}.39 \\
* * *\end{array}$ & $\begin{array}{l}.26 \\
* *\end{array}$ & .10 & .09 & .04 \\
\hline & 6 & .02 & .03 & .05 & $\begin{array}{l}.21 \\
*\end{array}$ & $\begin{array}{l}.38 \\
* * *\end{array}$ & $\begin{array}{l}.21 \\
*\end{array}$ & $\begin{array}{l}.25 \\
* *\end{array}$ & $\begin{array}{l}.28 \\
* *\end{array}$ & $\begin{array}{l}.24 \\
* *\end{array}$ & .15 & .07 & .07 \\
\hline Louisville & 2 & .01 & .04 & -.04 & .14 & $\begin{array}{l}.39 \\
* * *\end{array}$ & $\begin{array}{l}.29 \\
* *\end{array}$ & $\begin{array}{l}.42 \\
* * *\end{array}$ & $\begin{array}{l}.27 \\
* *\end{array}$ & $\begin{array}{l}.36 \\
* * *\end{array}$ & $\begin{array}{l}.22 \\
*\end{array}$ & $\begin{array}{l}.23 \\
*\end{array}$ & -.01 \\
\hline
\end{tabular}


Table 6. Kendall's tau rank correlation of monthly streamflow with monthly precipitation and monthly Palmer Hydrological Drought Indices for four climatic divisions drained by the Platte River from Duncan through Louisville, Nebraska, 1895-2006.-Continued

[Div., climate division; only Kendall's tau values followed by *,**, and *** are significantly different from zero at $p$-value less than $0.05,0.01$, and 0.001 , respectively]

\begin{tabular}{|c|c|c|c|c|c|c|c|c|c|c|c|c|c|}
\hline \multirow{2}{*}{$\begin{array}{c}\text { Station } \\
\text { name }\end{array}$} & \multirow{2}{*}{ Div. } & \multicolumn{12}{|c|}{ Palmer Hydrological Drought Indices } \\
\hline & & January & February & March & April & May & June & July & August & September & October & November & December \\
\hline Duncan & 5 & $\begin{array}{l}.48 \\
* * *\end{array}$ & $\begin{array}{l}.56 \\
* * *\end{array}$ & $\begin{array}{l}.39 \\
* * *\end{array}$ & $\begin{array}{l}.52 \\
* * *\end{array}$ & $\begin{array}{l}.46 \\
* * *\end{array}$ & $\begin{array}{l}.44 \\
* * *\end{array}$ & $\begin{array}{l}.50 \\
* * *\end{array}$ & $\begin{array}{l}.55 \\
* * *\end{array}$ & $\begin{array}{l}.56 \\
* * *\end{array}$ & $\begin{array}{l}.59 \\
* * *\end{array}$ & $\begin{array}{l}.54 \\
* * *\end{array}$ & $\begin{array}{l}.57 \\
* * *\end{array}$ \\
\hline \multirow[t]{2}{*}{ North Bend } & 2 & $\begin{array}{l}.34 \\
* * *\end{array}$ & $\begin{array}{l}.34 \\
* * *\end{array}$ & $\begin{array}{l}.33 \\
* * *\end{array}$ & $\begin{array}{l}.39 \\
* * *\end{array}$ & $\begin{array}{l}.42 \\
* * *\end{array}$ & $\begin{array}{l}.34 \\
* * *\end{array}$ & $\begin{array}{l}.43 \\
* * *\end{array}$ & $\begin{array}{l}.41 \\
* * *\end{array}$ & $\begin{array}{l}.36 \\
* * *\end{array}$ & $\begin{array}{l}.39 \\
* * *\end{array}$ & $\begin{array}{l}.41 \\
* * *\end{array}$ & $\begin{array}{l}.55 \\
* * *\end{array}$ \\
\hline & 5 & $\begin{array}{l}.37 \\
* * *\end{array}$ & $\begin{array}{l}.45 \\
* * *\end{array}$ & $\begin{array}{l}.34 \\
* * *\end{array}$ & $\begin{array}{l}.44 \\
* * *\end{array}$ & $\begin{array}{l}.38 \\
* * *\end{array}$ & $\begin{array}{l}.31 \\
* * *\end{array}$ & $\begin{array}{l}.43 \\
* * *\end{array}$ & $\begin{array}{l}.37 \\
* * *\end{array}$ & $\begin{array}{l}.36 \\
* * *\end{array}$ & $\begin{array}{l}.41 \\
* * *\end{array}$ & $\begin{array}{l}.40 \\
* * *\end{array}$ & $\begin{array}{l}.52 \\
* * *\end{array}$ \\
\hline \multirow[t]{2}{*}{ Leshara } & 2 & $\begin{array}{l}.42 \\
* * *\end{array}$ & $\begin{array}{l}.42 \\
* * *\end{array}$ & $\begin{array}{l}.41 \\
* * *\end{array}$ & $\begin{array}{l}.56 \\
* * *\end{array}$ & $\begin{array}{l}.44 \\
* * *\end{array}$ & $\begin{array}{l}.40 \\
* * *\end{array}$ & $\begin{array}{l}.36 \\
* * *\end{array}$ & $\begin{array}{l}.43 \\
* * *\end{array}$ & $\begin{array}{l}.43 \\
* * *\end{array}$ & $\begin{array}{l}.39 \\
* * *\end{array}$ & $\begin{array}{l}.45 \\
* * *\end{array}$ & $\begin{array}{l}.36 \\
* * *\end{array}$ \\
\hline & 6 & $\begin{array}{l}.33 \\
* * *\end{array}$ & $\begin{array}{l}.40 \\
* * *\end{array}$ & $\begin{array}{l}.51 \\
* * *\end{array}$ & $\begin{array}{l}.54 \\
* * *\end{array}$ & $\begin{array}{l}.49 \\
* * *\end{array}$ & $\begin{array}{l}.37 \\
* * *\end{array}$ & $\begin{array}{l}.32 \\
* * *\end{array}$ & $\begin{array}{l}.37 \\
* * *\end{array}$ & $\begin{array}{l}.38 \\
* * *\end{array}$ & $\begin{array}{l}.33 \\
* * *\end{array}$ & $\begin{array}{l}.39 \\
* * *\end{array}$ & $\begin{array}{l}.18 \\
*\end{array}$ \\
\hline \multirow[t]{3}{*}{ Ashland } & 2 & $\begin{array}{l}.31 \\
* * *\end{array}$ & $\begin{array}{l}.40 \\
* * *\end{array}$ & $\begin{array}{l}.47 \\
* * *\end{array}$ & $\begin{array}{l}.57 \\
* * *\end{array}$ & $\begin{array}{l}.46 \\
* * *\end{array}$ & $\begin{array}{l}.38 \\
* * *\end{array}$ & $\begin{array}{l}.42 \\
* * *\end{array}$ & $\begin{array}{l}.45 \\
* * *\end{array}$ & $\begin{array}{l}.44 \\
* * *\end{array}$ & $\begin{array}{l}.32 \\
* * *\end{array}$ & $\begin{array}{l}.42 \\
* * *\end{array}$ & $\begin{array}{l}.37 \\
* * *\end{array}$ \\
\hline & 3 & $\begin{array}{l}.22 \\
*\end{array}$ & $\begin{array}{l}.38 \\
* * *\end{array}$ & $\begin{array}{l}.50 \\
* * *\end{array}$ & $\begin{array}{l}.46 \\
* * *\end{array}$ & $\begin{array}{l}.44 \\
* * *\end{array}$ & $\begin{array}{l}.36 \\
* * *\end{array}$ & $\begin{array}{l}.40 \\
* * *\end{array}$ & $\begin{array}{l}.40 \\
* * *\end{array}$ & $\begin{array}{l}.38 \\
* * *\end{array}$ & $\begin{array}{l}.29 \\
* * *\end{array}$ & $\begin{array}{l}.37 \\
* * *\end{array}$ & $\begin{array}{l}.33 \\
* * *\end{array}$ \\
\hline & 5 & $\begin{array}{l}.31 \\
* * *\end{array}$ & $\begin{array}{l}.42 \\
* * *\end{array}$ & $\begin{array}{l}.55 \\
* * *\end{array}$ & $\begin{array}{l}.56 \\
* * *\end{array}$ & $\begin{array}{l}.47 \\
* * *\end{array}$ & $\begin{array}{l}.38 \\
* * *\end{array}$ & $\begin{array}{l}.44 \\
* * *\end{array}$ & $\begin{array}{l}.46 \\
* * *\end{array}$ & $\begin{array}{l}.43 \\
* * *\end{array}$ & $\begin{array}{l}.33 \\
* * *\end{array}$ & $\begin{array}{l}.44 \\
* * *\end{array}$ & $\begin{array}{l}.33 \\
* * *\end{array}$ \\
\hline & 5 & $\begin{array}{l}.51 \\
* * *\end{array}$ & $\begin{array}{l}.57 \\
* * *\end{array}$ & $\begin{array}{l}.51 \\
* * *\end{array}$ & $\begin{array}{l}.66 \\
* * *\end{array}$ & $\begin{array}{l}.53 \\
* * *\end{array}$ & $\begin{array}{l}.39 \\
* * *\end{array}$ & $\begin{array}{l}.50 \\
* * *\end{array}$ & $\begin{array}{l}.56 \\
* * *\end{array}$ & $\begin{array}{l}.52 \\
* * *\end{array}$ & $\begin{array}{l}.67 \\
* * *\end{array}$ & $\begin{array}{l}.67 \\
* * *\end{array}$ & $\begin{array}{l}.58 \\
* * *\end{array}$ \\
\hline & 6 & $\begin{array}{l}.39 \\
* * *\end{array}$ & $\begin{array}{l}.45 \\
* * *\end{array}$ & $\begin{array}{l}.52 \\
* * *\end{array}$ & $\begin{array}{l}.62 \\
* * *\end{array}$ & $\begin{array}{l}.58 \\
* * *\end{array}$ & $\begin{array}{l}.40 \\
* * *\end{array}$ & $\begin{array}{l}.51 \\
* * *\end{array}$ & $\begin{array}{l}.55 \\
* * *\end{array}$ & $\begin{array}{l}.44 \\
* * *\end{array}$ & $\begin{array}{l}.57 \\
* * *\end{array}$ & $\begin{array}{l}.57 \\
* * *\end{array}$ & $\begin{array}{l}.40 \\
* * *\end{array}$ \\
\hline
\end{tabular}




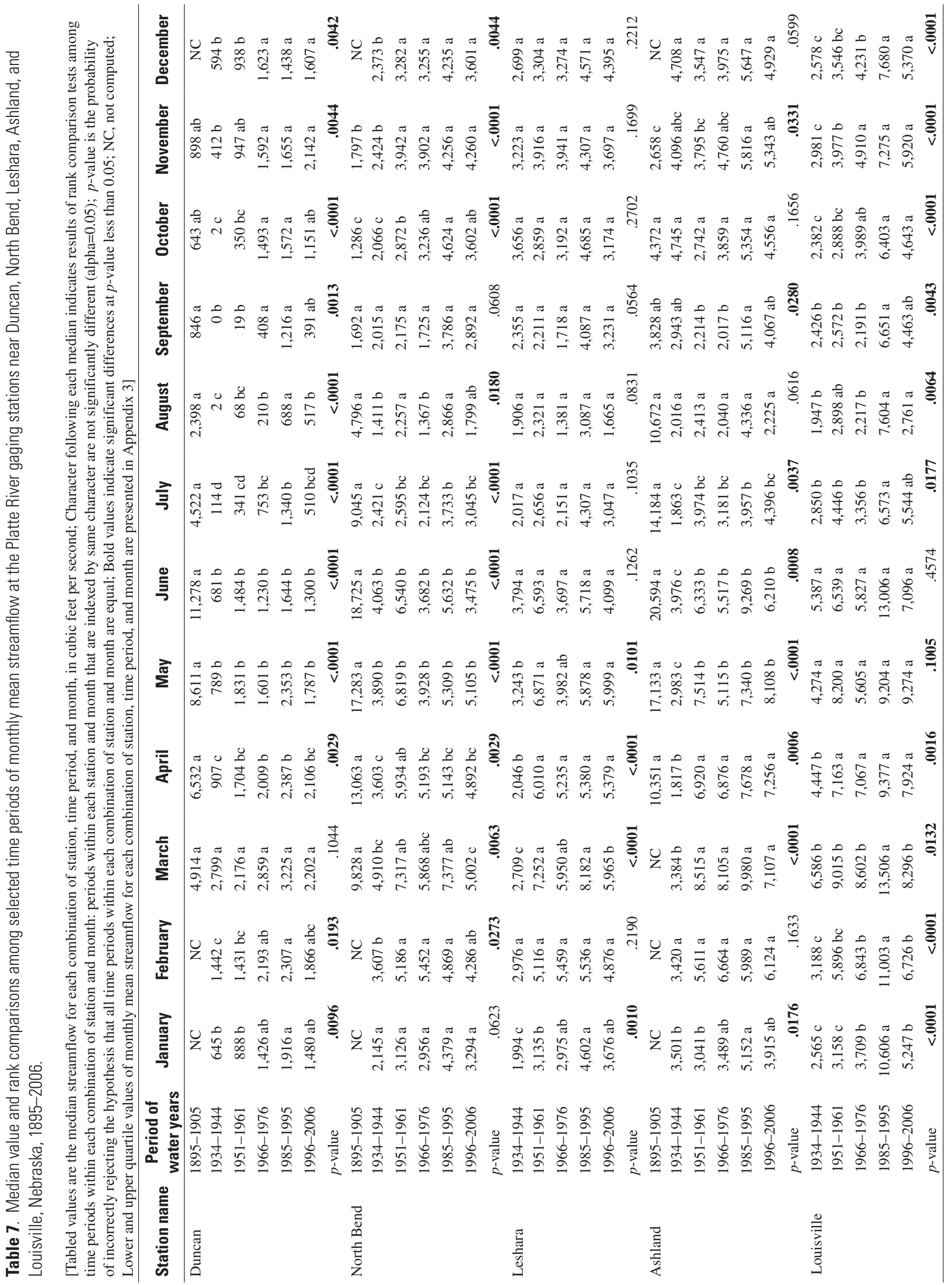




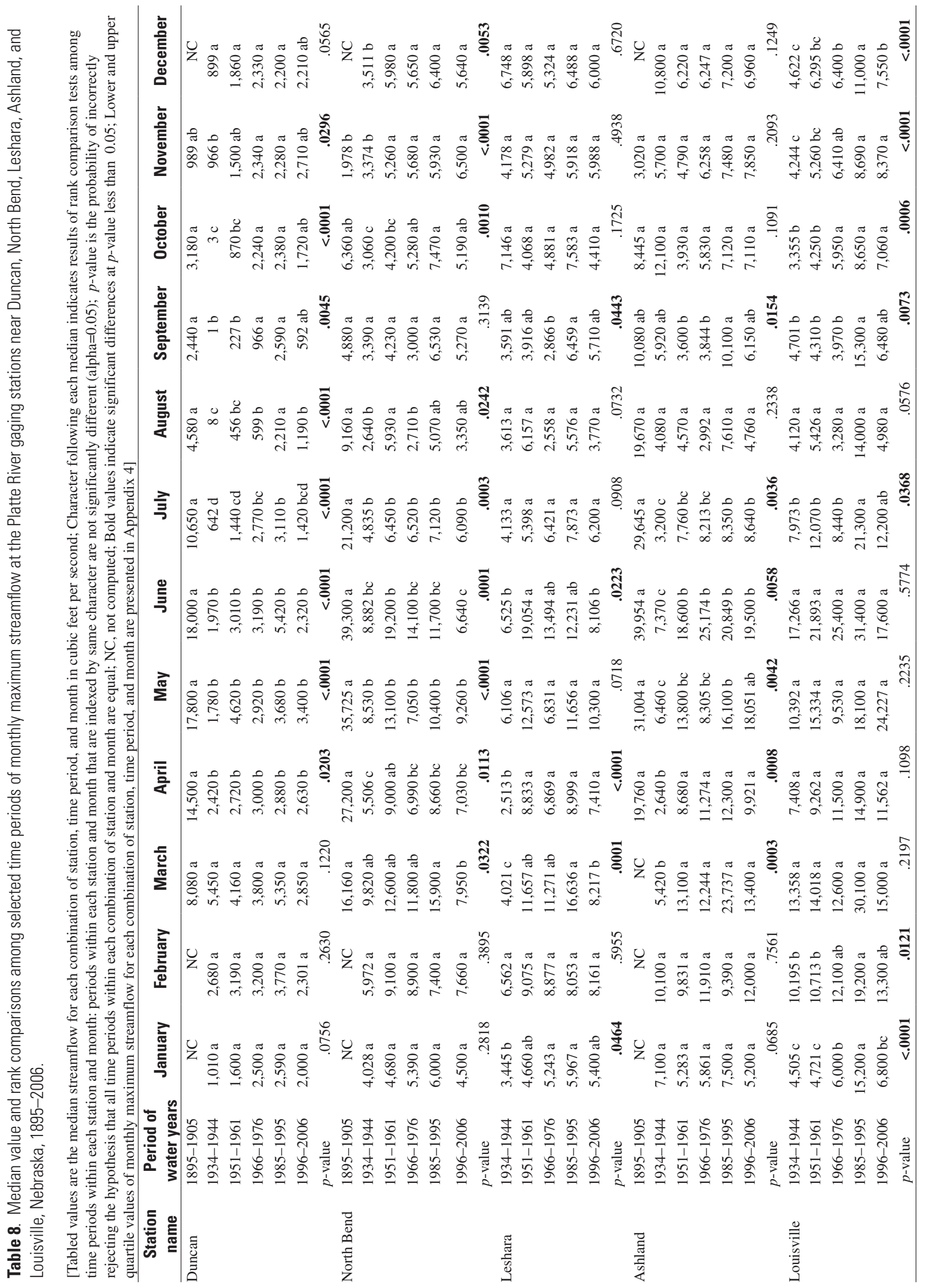




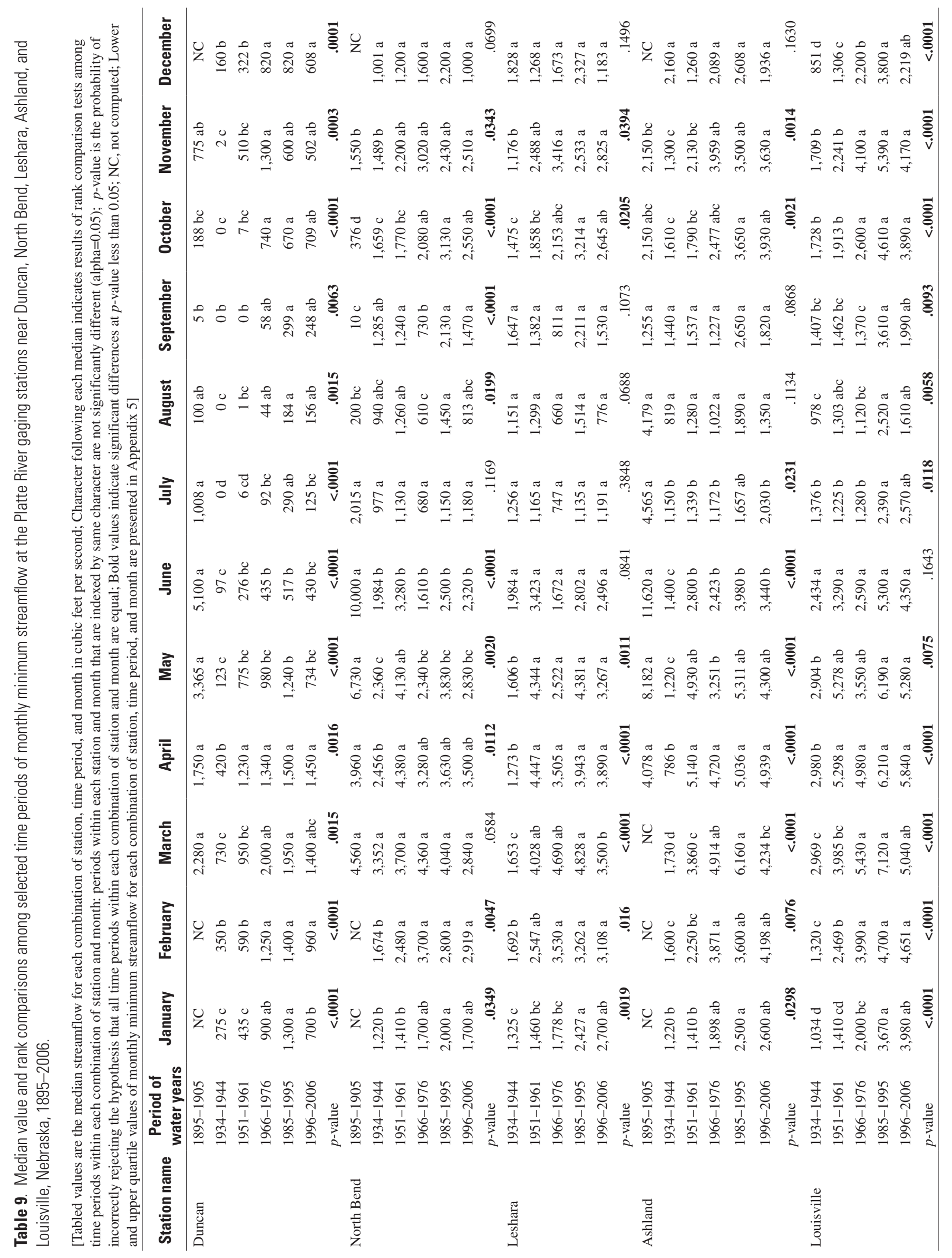




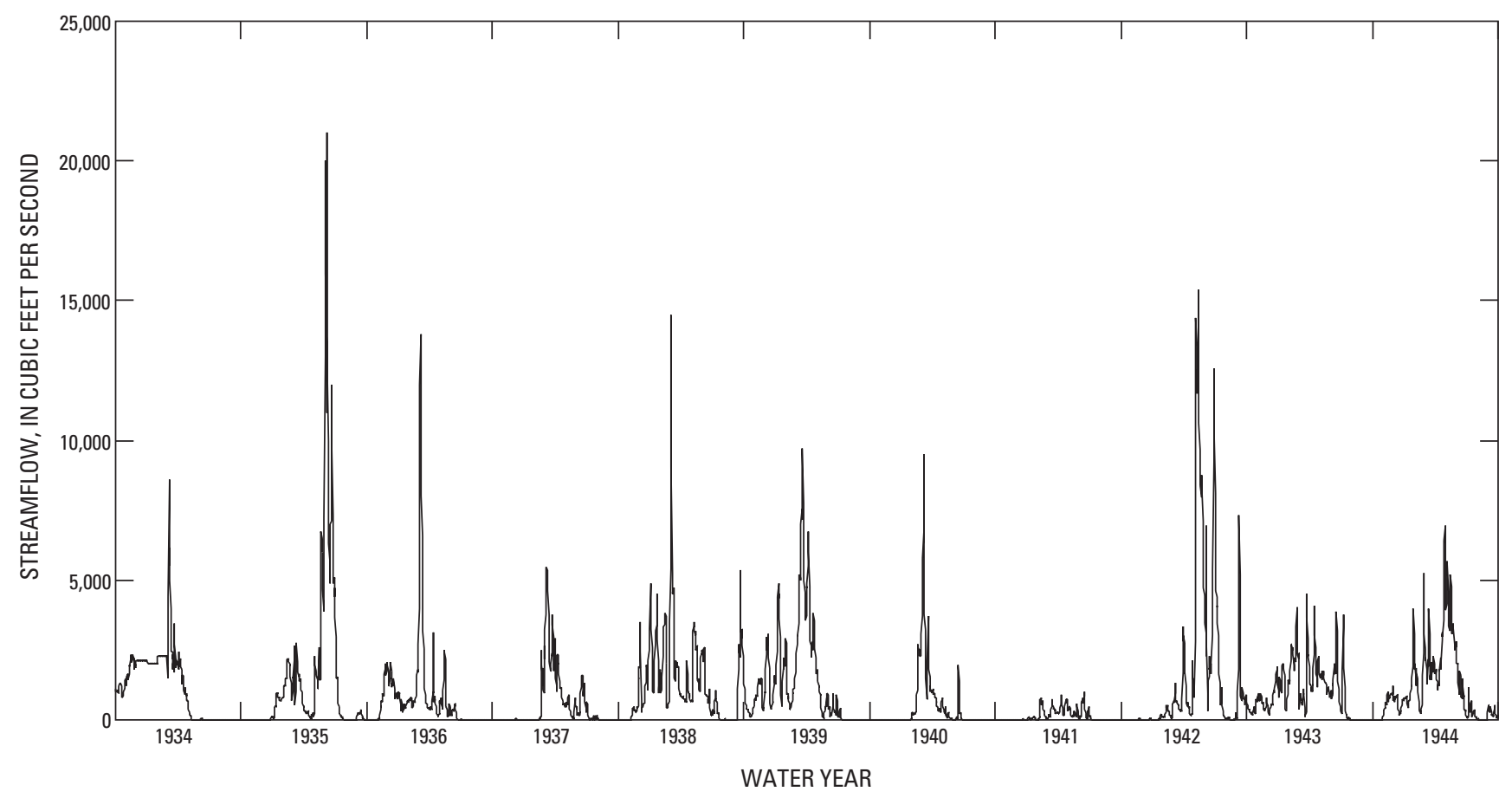

Figure 3. Daily streamflow hydrograph for the central Platte River system near Duncan, Nebraska, during the 1934-44 drought period.

system in the 1934-44 drought period, especially from August to September, were indicative of large numbers of low or zero values of daily mean streamflow but with some extremely high values as well (fig. 3). During a moderately wet 1985-95 period, the skewness was generally less than that for the 1934-1944 period, indicating that daily streamflow values were more evenly distributed around the mean (fig. 4).

Generally the monthly coefficients of skewness and variation in streamflow for the lower Platte River stations were not significantly different among the periods. However, monthly coefficients of skewness of streamflow in either the 19341944 or 1951-1961 periods were larger than one or more other 11-water-year periods for month and station combinations that showed significant temporal differences in skewness. Coefficients of skewness and variation were likely to be smaller in the 1985-95 or 1996-2006 periods than those in the 1934-44 period (table 10 and 11). Neither of the 1985-95 or 19962006 periods was persistently in drought, except in climate division 6, whereas the 1934-44 and 1951-61 periods contained several drought years, and multiple months had median PHDI values less than -1 (mild drought or worse) in climate division 2 and 5 .

There was no difference among the periods in coefficients of skewness of streamflow for all months (table 10) at Louisville station, the most downstream station on the lower Platte River. At Louisville, the influence of climatic conditions in climate division 6 is greater than at the upstream stations, and the conditions (PHDI median values) during the 1951-1961 and 1996-2006 periods in climate division 6 tended to offset those in other parts of the Platte River basin, probably reducing the coefficient of skewness.

\section{Temporal Differences in Nonredundant Hydrologic Indices}

Eighteen indices of the 27 selected nonredundant HIs indicated existence of temporal differences among the periods (table 12). Eleven of the nonredundant indices were indicators of streamflow variability. The monthly coefficients of skewness and coefficients of variation of streamflow, and the count of nonredundant indices that evidenced temporal differences among the periods, together pointed to the different streamflow regimes of the central Platte River system at Duncan station and the stations on the lower Platte River system. Seven of 13 indices for the central Platte River system at Duncan station that indicated temporal differences were indices of flow variability; for the lower Platte River stations, five of nine indices that evidenced temporal differences were indices of streamflow variability.

\section{Magnitude of Streamflow Events}

There was generally no potential difference among the periods in streamflow magnitude indices for the lower Platte River stations; but for the streamflow magnitude indices from the central Platte River system at Duncan station, three of five potentially differed among periods (table 13). Variability across annual discharge (MA43) for Duncan station in the 


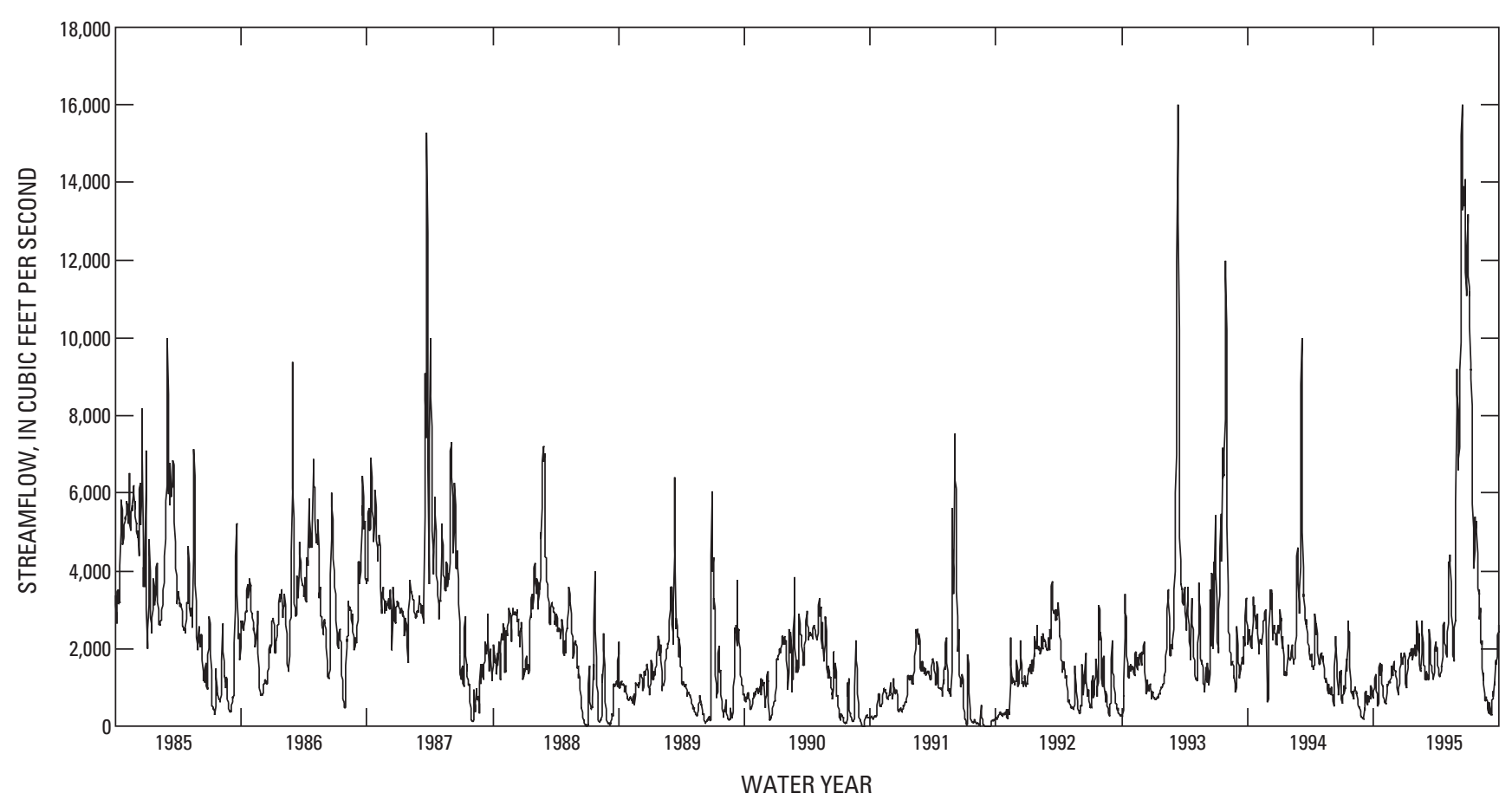

Figure 4. Daily streamflow hydrograph for the central Platte River system near Duncan, Nebraska during the 1985-95 moderately wet period.

1996-2006 period was highest among the periods, perhaps because this period contained five wet years (1996-2000) and six drought years (2001-2006). Variability across monthly minimum streamflow values (ML13) was highest in the 1934-44 period indicating that when expressed as a percentage, variability of streamflow tends to be larger when mean streamflow is less; the ratio of total discharge to base flow (ML20) also was the lowest in the 1934-44 period. Variability in base flow (ML18) in the 1934-44 and 1951-61 periods also was higher than that in the other periods. High peak flow (MH26) potentially did not differ among the periods for the two stations upstream from Leshara, but for each of the three downstream stations, relative magnitude of peak flows was potentially less during 1996-2006 than during one or more of the periods during 1934-95. Recalling that, based on the median PHDI values, the drought during the 1996-2006 period was more pronounced in climate division 6 than in the remaining climate divisions considered for this study, the probable temporal differences involving the 1996-2006 period at or downstream from Leshara is reasonable. Also, these results may indicate that during this period there were fewer high streamflow values meeting the streamflow criterion (equal or greater than seven times of median streamflow during each period) to be included in the set used to calculate MH26 (a criterion that varies relative to the median streamflow during each period).

\section{Frequency of Streamflow Events}

There were potential temporal differences in flood frequency in all three stations downstream from North Bend, using a minimum threshold equal to the streamflow with 25-percent exceedence (FH8) (table 13). At each station, the frequency of HIP-defined high-flow events potentially was greater during the 1934-1944 drought period than during the mildly wet 1966-1976 period. Once again, note that the criterion for inclusion of high-flow events in the set used to calculate FH8 varies relative to the threshold during each period for each station. Variability in low-flood pulse count (FL2) and the variability in high-flow pulse count (FH2) were highest in the 1996-2006 period (table 13) because this period was a mixture of five wet years (1996-2000) and six drought years. Recalling HIP-defined low flood (table 13), the maximum threshold for inclusion of low flood count varies among period and station combinations; therefore, the mean counts of lowflood pulses also varies among period and station combinations. Except for the streamflow from the central Platte River system, the frequency of low-pulse spells (FL3) and flood frequency using a threshold equal to seven times the median flow (FH7) generally indicated no differences among the periods. The FL3 and FH7 during the 1934-44 and 1951-61 periods in the central Platte River system at Duncan station were higher than those in the other periods (table 13). 


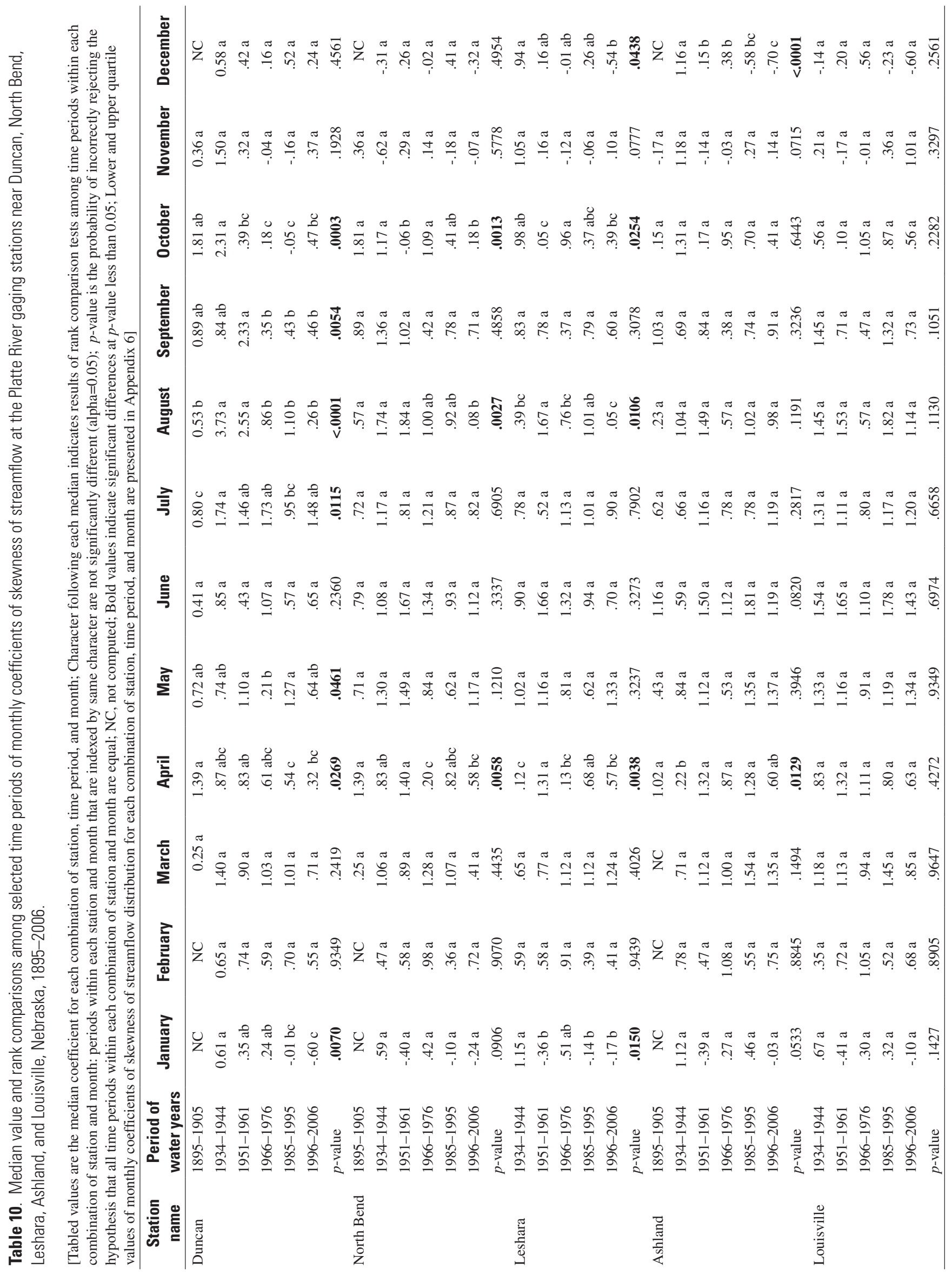




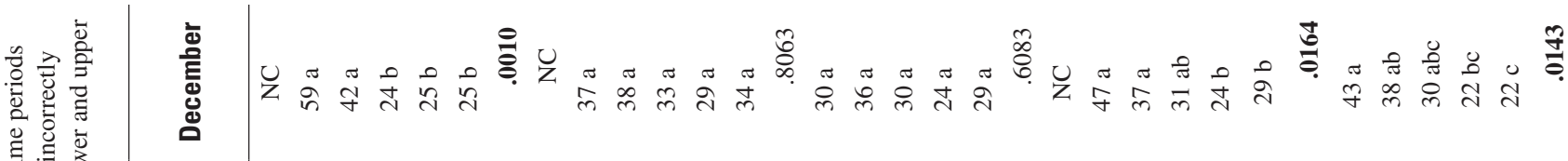

○.

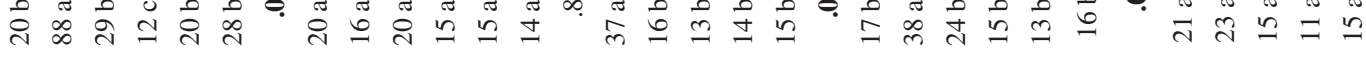

क⿻

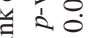

药

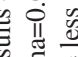

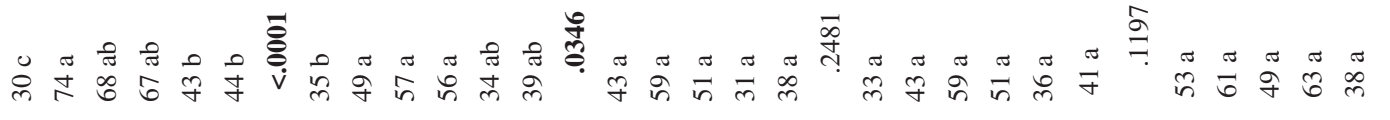

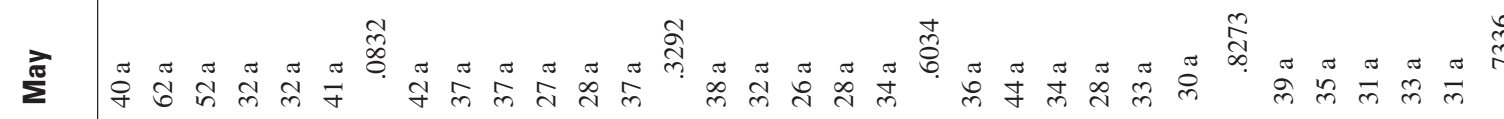

位

远

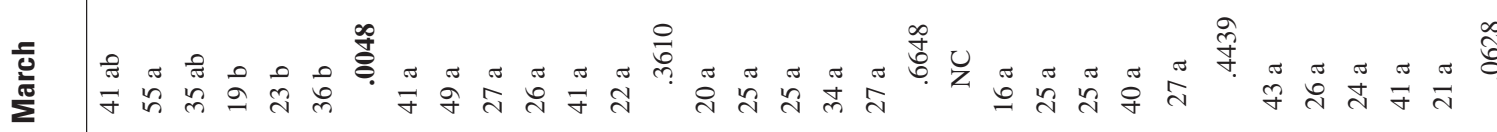

需

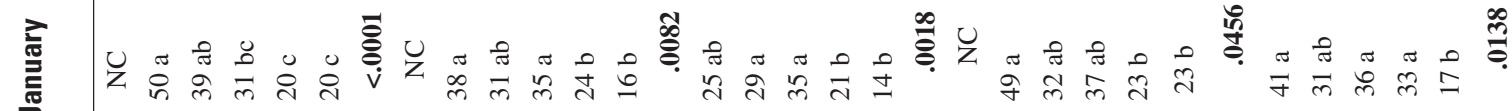


Table 12. Existence of probable temporal differences in nonredundant hydrologic indices of streamflow-regime categories for Platte River gaging stations near Duncan, North Bend, Leshara, Ashland, and Louisville, Nebraska, 1934-2006.

[x, statistical comparisons indicated that temporal differences potentially existed among the 11-water-year periods: 1934-1944, 1951-1961, 1966-1976, 1985-1995, and 1996-2006; --, statistical comparison indicated no temporal difference among period; Definitions of hydrologic indices are presented in table 3]

\begin{tabular}{|c|c|c|c|c|c|c|}
\hline \multirow{2}{*}{ Category } & \multirow{2}{*}{ Nonredundant hydrologic indices } & \multicolumn{5}{|c|}{ Stations } \\
\hline & & Duncan & North Bend & Leshara & Ashland & Louisville \\
\hline \multirow[t]{3}{*}{ Magnitude } & Variability across annual discharge (MA43) & $\mathrm{x}$ & -- & -- & -- & -- \\
\hline & Ratio of total discharge and base streamflow (ML20) & $\mathrm{x}$ & -- & -- & -- & -- \\
\hline & High peak streamflow (MH26) & -- & -- & $\mathrm{x}$ & $\mathrm{x}$ & $\mathrm{x}$ \\
\hline \multirow[t]{3}{*}{ Frequency } & Variability in low-flood pulse count (FL2) & $\mathrm{x}$ & $\mathrm{x}$ & $\mathrm{x}$ & $\mathrm{x}$ & $\mathrm{x}$ \\
\hline & Frequency of low pulse spells (FL3) & $\mathrm{x}$ & -- & -- & -- & -- \\
\hline & Variability in high-streamflow pulse count (FH2) & $\mathrm{x}$ & $\mathrm{x}$ & $\mathrm{x}$ & $\mathrm{x}$ & $\mathrm{x}$ \\
\hline \multirow{7}{*}{ Duration } & Low exeedence streamflow (DL14) & $\mathrm{x}$ & -- & -- & -- & -- \\
\hline & Variability in low pulse duration (DL17) & $\mathrm{x}$ & $\mathrm{x}$ & $\mathrm{x}$ & $\mathrm{x}$ & $\mathrm{x}$ \\
\hline & Variability in the number of zero-streamflow days (DL19) & $\mathrm{x}$ & -- & -- & -- & -- \\
\hline & Annual maximum daily streamflow (ft $3 / \mathrm{s})(\mathrm{DH} 1)$ & -- & -- & -- & -- & -- \\
\hline & $\begin{array}{l}\text { Annual maximum of } 3 \text {-day moving average streamflow }\left(\mathrm{ft}^{3} / \mathrm{s}\right) \\
(\mathrm{DH} 2)\end{array}$ & -- & -- & -- & -- & -- \\
\hline & $\begin{array}{l}\text { Variability of annual maximum of 1-day moving average } \\
\text { streamflow (DH6) }\end{array}$ & -- & -- & $\mathrm{x}$ & $\mathrm{x}$ & $\mathrm{x}$ \\
\hline & $\begin{array}{l}\text { Variability of annual maximum of 3-day moving average } \\
\text { streamflow (DH7) }\end{array}$ & -- & -- & $\mathrm{x}$ & $\mathrm{x}$ & $\mathrm{x}$ \\
\hline \multirow{4}{*}{ Rate of change } & Fall rate (RA3) & -- & -- & -- & -- & -- \\
\hline & Variability (coefficient of variation) of rise rate (RA2) & -- & -- & -- & -- & -- \\
\hline & Variability in fall rate (RA4) & -- & -- & -- & -- & -- \\
\hline & Streamflow fluctuations (RA8) & -- & $\mathrm{x}$ & $\mathrm{x}$ & -- & -- \\
\hline
\end{tabular}




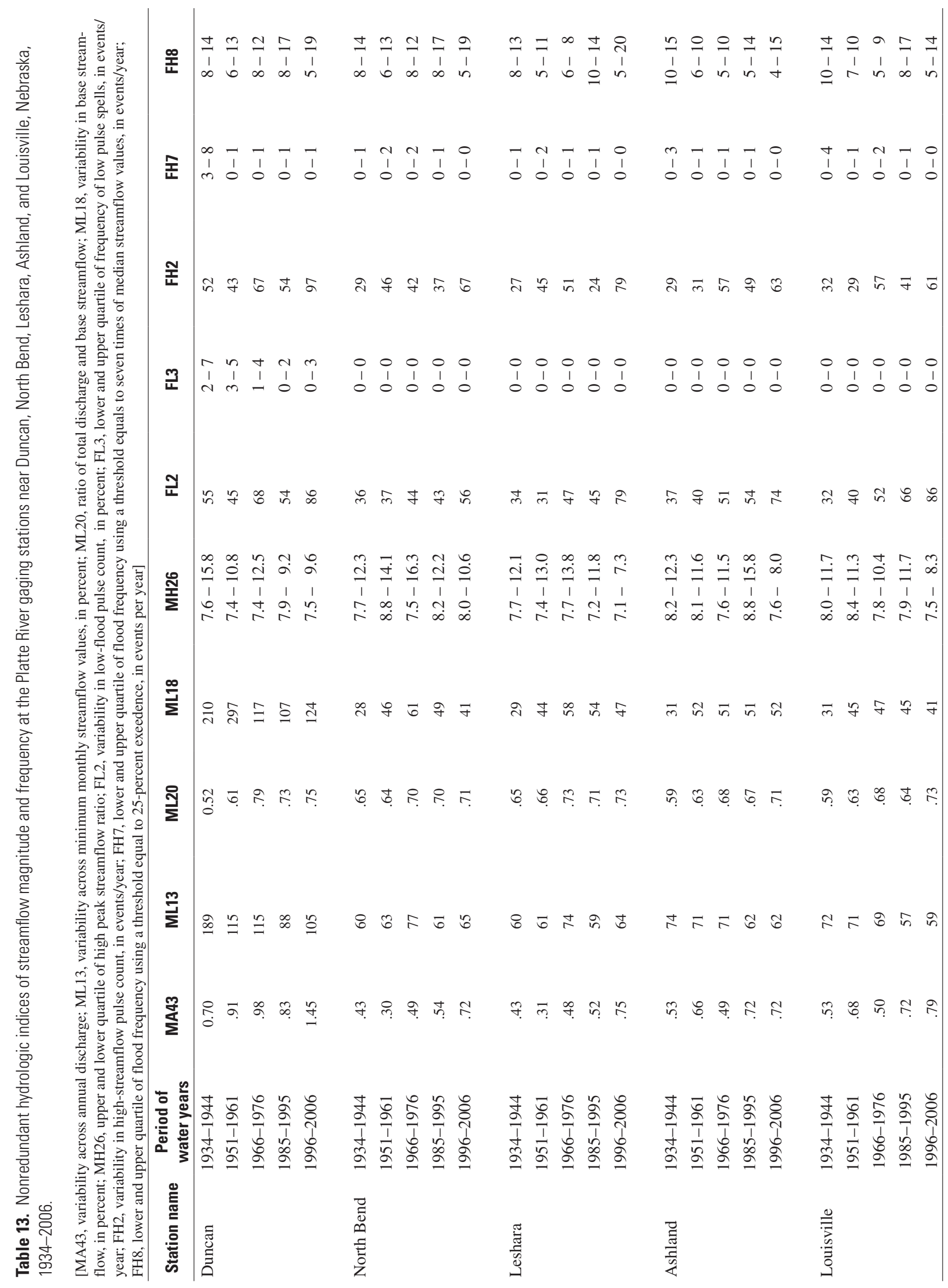




\section{Duration of Streamflow Events}

Temporal differences for low-flow duration indices were mainly evident for the outflow from the central Platte River system at Duncan; annual minimum daily streamflow (DL1), low exceedence flows (DL14), and variability in the number of zero-flow days (DL19) were lowest in the 1934-44 drought period especially compared to the moderately wet 1985-95 period (table 14). Temporal differences in DL1 between the dry 1934-44 period and the wet 1985-95 period also were evidenced for the lower Platte River system at Ashland and Louisville stations. Once again, these potential temporal differences contrast the driest and wettest periods, based on the PHDI values. Variability in low-flow pulse duration (DL17) for all stations consistently was highest in the 1966-76 period.

Three of five high-streamflow duration indices, that is, annual maximum daily flow (DH1), annual maximum of 3-day moving-average flow (DH2), and flood duration (DH14) did not differ among the periods. The other two, that is, variability of annual maximum of 1-day moving-average flows (DH6) and variability of annual maximum of 3-day moving-average flows (DH7) (table 14) evidenced potential differences among periods. The DH6 and DH7 variability indices were the least during the 1996-2006 period for all the stations on the lower Platte River. Once again, note that the DH6 and DH7 were calculated relative to the mean of annual maximum of 1-day moving-average streamflow and the mean of annual maximum of 3-day moving-average streamflow values, respectively, which varied among station and period combinations.

\section{Timing of Streamflow Events}

Temporal differences among the periods in streamflow timing indices were inconclusive, in part because of lack of peak streamflow data for years when gaging stations were inactive. Seasonal predictability of flooding (TA3), the seasonal predictability of nonlow streamflow (TL4), and the seasonal predictability of nonflooding (TH3) indices for some station-period combinations could not be computed by the HIP software because peak streamflow data were unavailable (table 15). This limitation did not affect Duncan station, which indicated that the TL4 values were the least in the dry 1934-44 period. The TL4 refers to the maximum proportion of the year (number of days/365) during which streamflow was above the 5-year-flood threshold (table 3).

\section{Rate of Change of Streamflow Events}

Generally there were no temporal differences in the indices of rate of change for the rise rate (RA1), variability of rise rate (RA2), fall rate (RA3), and variability in fall rate (RA4) for any stations on the Platte River. Number of streamflow fluctuations (RA8) for the lower Platte River gaging stations was generally higher in the 1966-76, 1985-95, and 1996-2006 periods than in the 1934-44 and 1951-61 periods for North Bend and Leshara stations (table 15). The temporal differences in part were caused by the climate differences among these periods. The majority of streamflow at North Bend and Leshara stations originates from the Loup River and Shell Creek systems, which are under climatic division 2 and 5. Correlation analysis evidenced positive and significant correlation of the annual streamflow fluctuations at North Bend with annual median PHDI values of climate division 5 (Kendall's tau $=0.22, p=0.02$ ); although at Leshara station, the correlation was positive but not significant (Kendall's tau $=0.22, p=0.18$ ). Positive correlation indicated more streamflow fluctuations as the PHDI increased (wetter).

Additional inspection of annual number of fluctuations also indicated that the variability in annual streamflow fluctuations was higher in the 1985-95 and 1996-2006 periods for North Bend and Leshara stations. Streamflow at North Bend and Leshara stations are mainly from the Loup River, whose water is diverted to the Loup Power Canal http://www.loup.com/elec-gen.asp, verified November 14, 2007). Perhaps streamflow fluctuations from hydroelectric generation traveled and were detected downstream at North Bend and Leshara stations. As the streamflow traveled further downstream and joined the streamflow from the Elkhorn River, no potential temporal difference in streamflow fluctuations was observed for Ashland station and further downstream at Louisville station. Note that RA8 indicates count of streamflow fluctuations, not the rate of fluctuations (table 3). These results and the variation in annual streamflow fluctuations indicates that increased streamflow regulation and management since 1962 may also play a part in the potential increased number of these fluctuations.

\section{Summary and Conclusion}

In cooperation with the Lower Platte South Natural Resources District for a collaborative study of the cumulative effects of water and channel management practices on stream and riparian ecology, the U.S. Geological Survey (USGS) compiled, analyzed, and summarized hydrologic information from long-term gaging stations on the lower Platte River to determine any significant temporal differences among six discrete periods during 1895-2006 and to interpret any significant changes in relation to changes in climatic conditions or other factors.

The lower Platte River basin was affected by moderate to severe drought conditions in the 1934-44 period. The widespread drought was preceded by mildly to moderately wet conditions in the 1895-1906 period, followed by incipient drought to incipiently wet conditions in the 1951-61 period and mildly wet condition in 1966-76 period, moderately wet conditions in the 1985-1995 period, and incipient drought to mildly wet conditions in the 1996-2006 period. Rank correlations of monthly streamflow and monthly Palmer Hydrological Drought Index (PHDI) were stronger than those of 


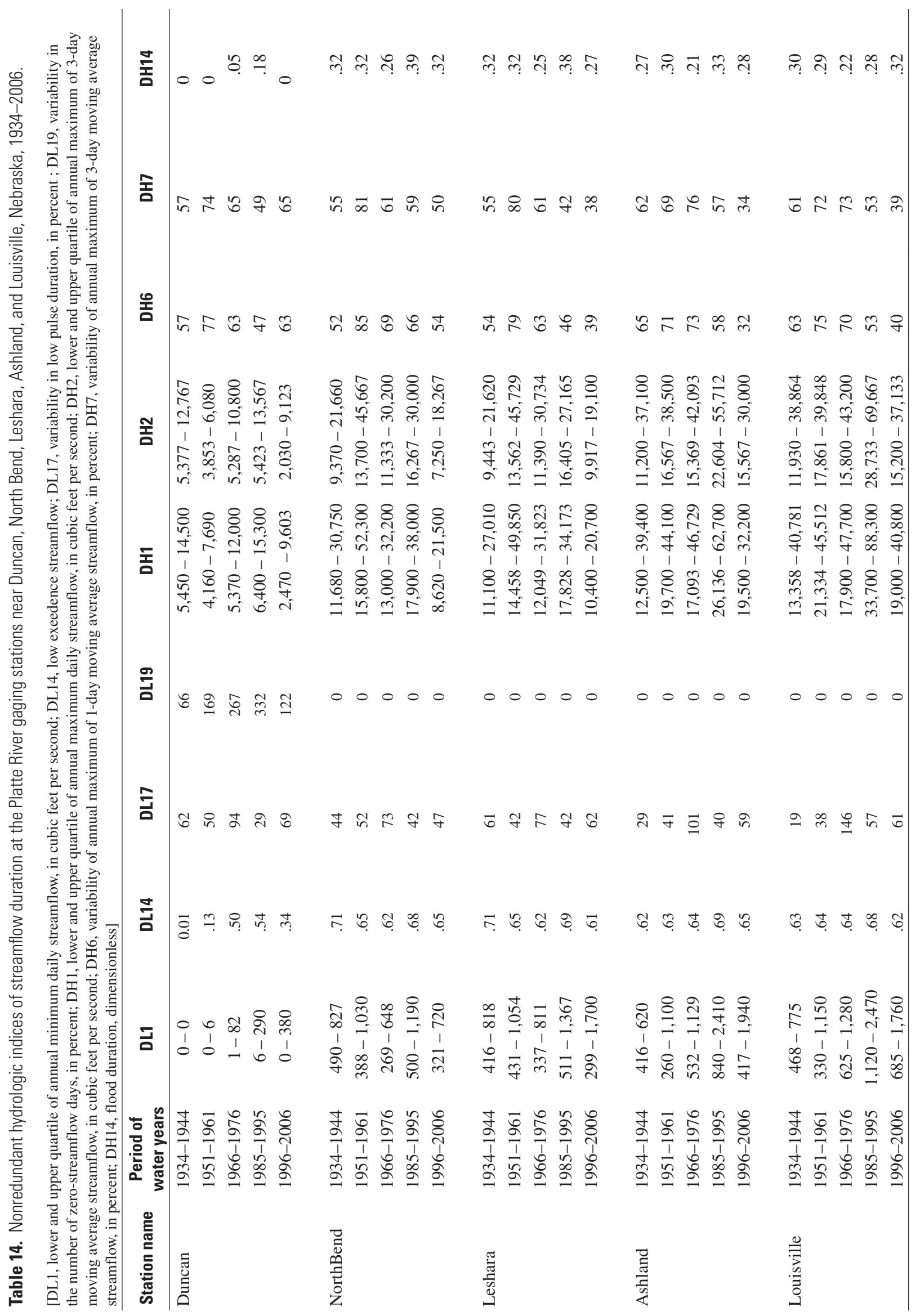




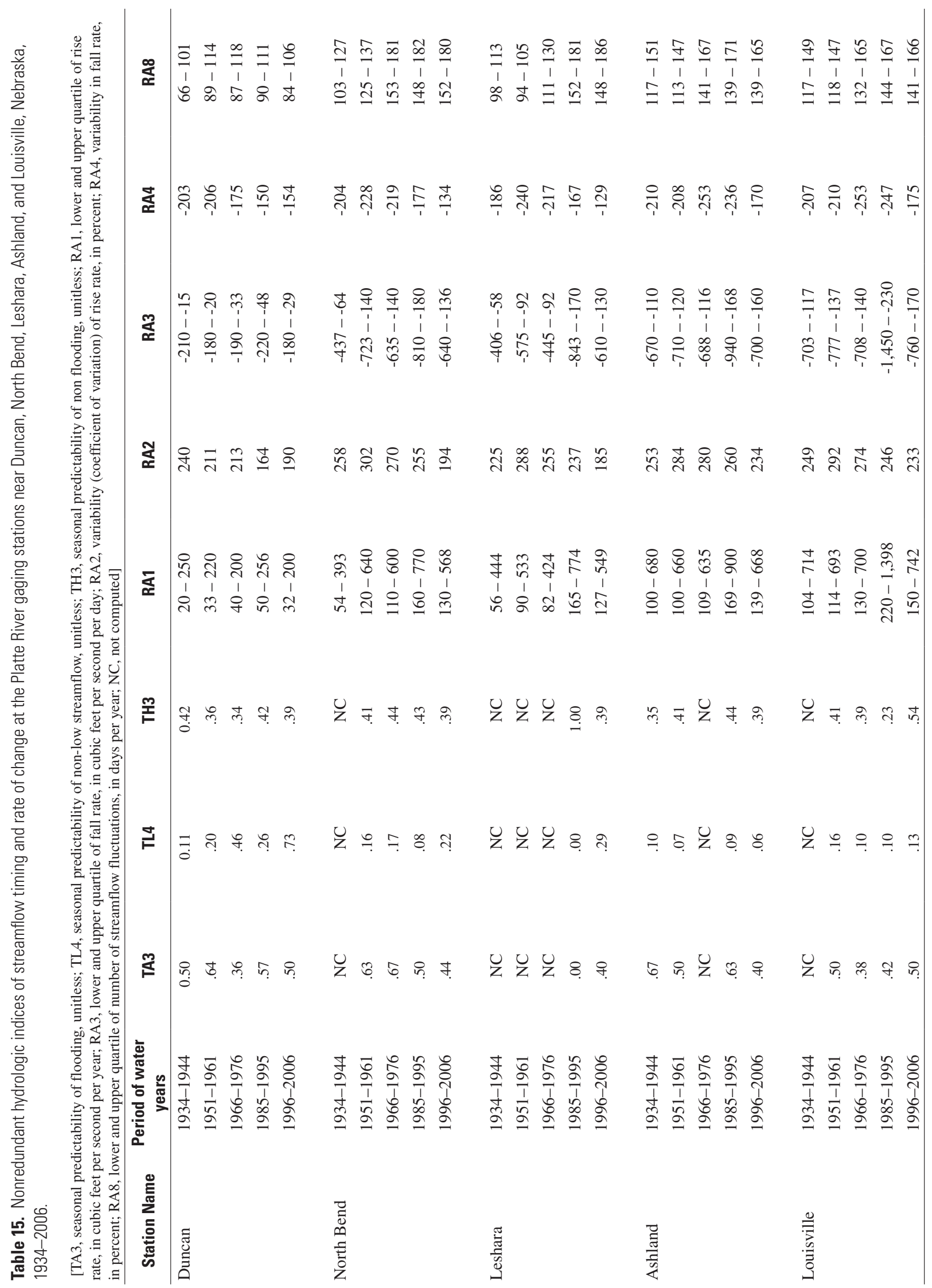


streamflow and monthly precipitation. Correlations of monthly streamflow with monthly PHDI were significant for all months and stations.

The temporal differences in monthly mean and monthly maximum streamflow between the two wet periods (18951905 and 1985-95) indicated the effects of increased storage and flow regulation on streamflow magnitude and amplitudethe difference between the highest and lowest median values of monthly mean streamflow. Monthly mean and monthly maximum streamflow from April through July (typically wet months) were the highest in the 1895-1905 period, the period prior to building of most major storage reservoirs and many other water management projects in the Platte River basin; however, during August through November (post-snowmelt months) the monthly streamflow in the 1895-1905 period were either less than or similar to those in the 1985-95 period. The effects of storage reservoirs and streamflow regulation on monthly minimum streamflow were less obvious.

The temporal differences among the other five periods, from 1934 through 2006 when major storage reservoirs were operational and streamflows were largely affected by regulation and water management, were dominated by contrasts between the periods with climate differences; the monthly mean, maximum, and minimum streamflow in the 1934-44 drought period were significantly lower than those in the 1985-96 moderately wet period. The temporal differences among the periods in monthly coefficients of streamflow skewness and variability were evident mainly for the central Platte River system at Duncan station. Skewness and variability of monthly streamflow generally were highest either in the 1934-44 or 1951-61 period for Duncan station, the periods of drought and mixed climatic conditions, respectively; the skewness coefficients generally were smallest in the 1985-1995 or 1996-2006 periods.

The skewness and variability of monthly flow, and the count of nonredundant indices that showed potential temporal differences among the periods, both pointed to a difference in streamflow regimes between the central Platte River system at Duncan station and the stations on the lower Platte River. Seven out of 13 indices for the central Platte River system at Duncan station that evidenced potential temporal differences were indices of flow variability; for the lower Platte River stations, five out of nine indices that evidenced potential temporal differences were indices of streamflow variability.

The nonredundant indices of the streamflow regime from the central Platte River system computed for Duncan station potentially had the largest variability in base flow and monthly minimum streamflow values, highest frequency of low-flow pulses, lowest flood frequency, largest number and least variability of zero-flow days, and largest variability of the daily and monthly flows during the 1934-44 and 1951-61 periods.

Nonredundant indices that evidenced potential temporal differences at two or more stations on the lower Platte River were: high peak streamflow (MH26), variability in low-flood pulse count (FL2), variability in high-flow pulse count (FH2), flood frequency (FH8), annual minimum daily streamflow
(DL1), variability in low-flow pulse duration (DL17), variability of annual maximum of 1-day moving-average streamflow (DH6), variability of annual maximum of 3-day movingaverage streamflow (DH7), and number of streamflow fluctuations (RA8). No other nonredundant indices indicated existence of temporal differences for the lower Platte River stations. The FL2 and FH2 indices were generally highest in the 1996-2006 period because this period was a mixture of five wet years (1996-2000) and six drought years. The RA8 was higher in the 1966-76, 1985-95, and 1996-2006 periods than those in the 1934-44 and 1951-61 periods, which associated with climate, streamflow regulation, and water management.

\section{Acknowledgments}

The authors wish to thank Larry Hutchinson, Nebraska Game and Parks Commission, for valuable suggestions during the planning stage. Thanks to the following colleagues for reviewing this manuscript: Christopher P. Konrad, Jim A. Henriksen, and Benjamin J. Dietsch of the U.S. Geological Survey.

\section{References Cited}

Dinan, John, Wingfield, G.A., and Sidle, J.G., 1993, Surveys of least terns and piping plovers in Nebraska, in Higgins, K.F., and Brashier, M.R., eds., The Missouri River and its tributaries_-piping plover and least tern symposium, Proceedings: Brookings, South Dakota State University, Cooperative Fish and Wildlife Research Unit, p. 205.

Dryer, M.P., and Sandvol, A.J., 1993, Recovery plan for the pallid sturgeon (Scaphirhynchus albus): Bismarck, N. Dak., U.S. Fish and Wildlife Service, 55 p.

Duncan, D.B., 1955, Multiple range and multiple F tests: Biometrics, v. 11, p 1-42.

Eschner, T.R., Hadley, R.F., and Crowley, K.D., 1983, Hydrologic and morphologic changes in channels of the Platte River Basin in Colorado, Wyoming, and Nebraska-A historical perspective: U.S Geological Survey Professional Paper 1277-A, 39 p.

Fitzpatrick, F.A., Waite, I.R., D’Arconte, P.J., Meador, M.R., Maupin, M.A., and Gurtz, M.E., 1998, Revised methods for characterizing stream habitat in the National Water-Quality Assessment Program: U.S. Geological Survey WaterResources Investigations Report 98-4052, 67 p.

Henriksen, J.A., Heasley, John, Kennen, J.G., and Nieswand, Steven, 2006, User's manual for the hydroecological integrity assessment process software: U.S. Geological Survey Open-File Report 2006-1093, 71 p. 
Helsel, D.R., and Hirsch, R.M., 1992, Statistical methods in water resources: Amsterdam, Elsevier, 529 p.

Jobson, H.E., 1989, User's manual for an open-channel streamflow model based on the diffusion analogy: U.S. Geological Survey Water-Resources Investigation Report 89-4133, 73 p.

Jordan, P.R., 1991, Assessment approach, in Jordan, P.R., and Stamer, J.K., eds., Surface water quality assessment of the lower Kansas River Basin, Kansas and Nebraska-Analysis of available data through 1986: U.S. Geological Survey Open-File Report 91-75, p. 21-24.

Kendall, Maurice, and Gibbons, J.D., 1990, Rank correlation methods (5th ed): New York, Oxford University Press, $260 \mathrm{p}$.

McKenney, Rose, 1997, Formation and maintenance of hydraulic habitat units in the streams of the Ozark Plateaus, Missouri and Arkansas: State College, Pennsylvania State University, Ph.D. dissertation, 340 p.

Moir, H.J., Soulsby, C., and Youngson, A.F., 1998, Hydraulic and sedimentary characteristics of habitat utilized by Atlantic salmon for spawning in the Girnock Burn, Scotland: Fisheries Management and Ecology, v. 5, p. 241-254.

National Climatic Data Center, 2007, NOAA Satellite and Information Service: National Climatic Data Center climate data available on the web, accessed May 31, 2007, at http://www.ncdc.noaa.gov/pub/data/cirs

National Research Council, 2005, The science of instream flows-A review of the Texas instream flow program: Washington, D.C., The National Academies Press, 162 p.

Nebraska Game and Parks Commission, 1993, Platte River instream flow: Lincoln, Nebraska Game and Parks Commission, 2 vol., separately paged, 43 and 29 p., appendices.

Olden, J.D., and Poff, N.L., 2003, Redundancy and the choice of hydrologic indices for characterizing streamflow regimes: River Research and Applications, v. 19, p. 101-121.

Poff, N.L., and Ward, J.V., 1989, Implications of streamflow variability and predictability for lotic community structure-A regional analysis of streamflow patterns: Canadian Journal of Fisheries and Aquatic Science, v. 46, p. 1805-1818.
Poff, N.L., Allan, J.D., Bain, M.B., Karr, J.R., and others, 1997, The natural flow regime-A new paradigm for riverine conservation and restoration: Bioscience, v. 47 , p. 769-784.

Richter, B.D., Baumgartner, J.V., Powel, Jennifer, and Braun, D.P., 1996, A method for assessing hydrologic alteration within ecosystems: Conservation Biology, v. 10, p. 11631174.

SAS Institute Inc., 1989, SAS/STAT User's Guide, version 6, 4th ed., v. 2: Cary, North Carolina, SAS Institute, 846 p.

SAS Institute Inc., 1990, SAS Procedures Guide, version 6, 3rd ed., Cary, North Carolina, SAS Institute, 705 p.

Stalnaker, C.B., Bovee, K.D., and Waddle, T.J., 1996, Importance of the temporal aspects of habitat hydraulics to fish population studies: Regulated Rivers Research and Management, v. 12, p. 145-153.

Stevens, J.C., 1909, Surface water supply of Nebraska: U.S. Geological Survey Water-Supply Paper 230, 251 p.

U.S. Fish and Wildlife Service, 1990, Recovery plan for the interior population of the least tern, Sterna antillarum: U.S. Fish and Wildlife Service, 90 p.

U.S. Fish and Wildlife Service, 1994, Draft revised recovery plan for piping plovers, Charadrius melodus, breeding in the Great Lakes and northern Great Plains: U.S. Fish and Wildlife Service, $121 \mathrm{p}$.

U.S. Geological Survey, 1958, Surface water supply of the United States 1955, Part 6-B, Missouri River Basin below Sioux City, Iowa: U.S. Geological Survey Water-Supply Paper 1390, 479 p.

U.S. Geological Survey, 2007. Surface-water daily data for Nebraska, National Water Information System: U.S. Geological Survey data available on the web, accessed May 31, 2007, at http://waterdata.usgs.gov/ne/nwis/dv

Wohl, E.E., 2001, Virtual rivers, lessons from the mountain rivers of the Colorado Front Range: New Haven, Conn., Yale Univ. Press, 210 p. 


\section{Appendixes}


Appendix 1. Lower and upper quartile values of monthly precipitation for the 11-water-year periods for four Nebraska climate divisions drained by the lower Platte River from Duncan through Louisville, Nebraska, 1895-2006.

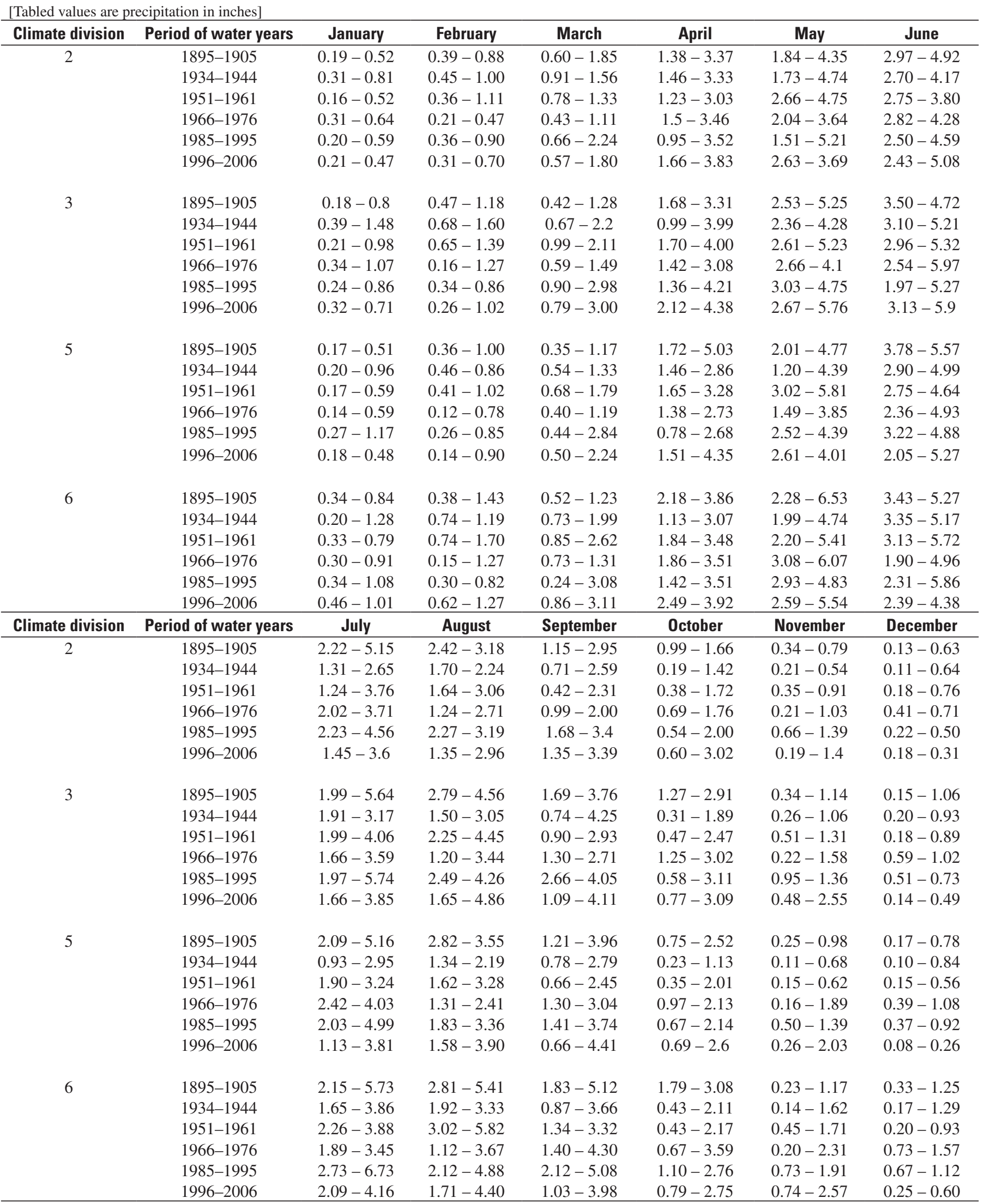


Appendix 2. Lower and upper quartile values of monthly Palmer Hydrological Drought Index, by climate division and 11-water-year period, for four Nebraska climate divisions drained by the lower Platte River from Duncan through Louisville, Nebraska, 1895-2006.

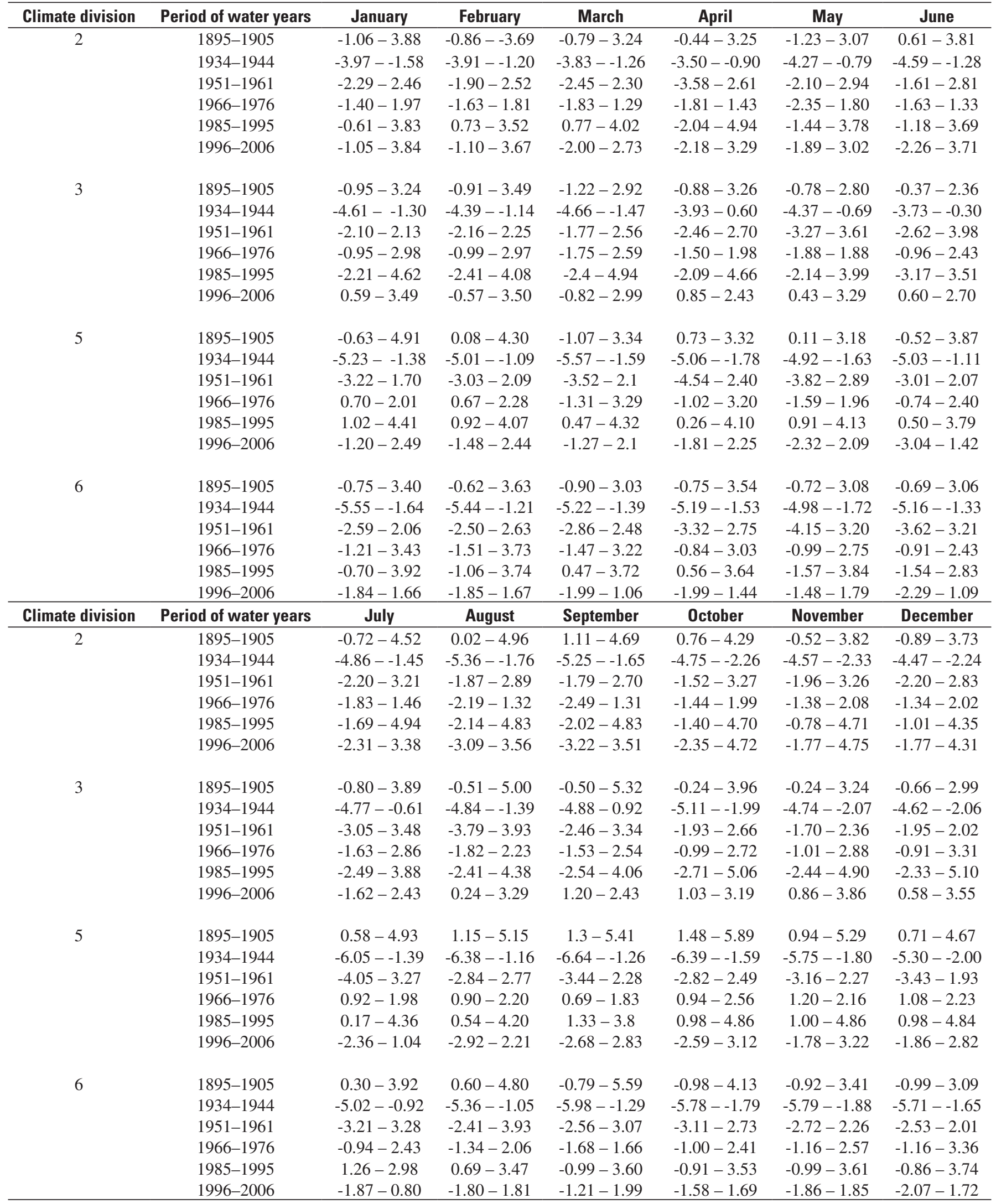


Appendix 3. Lower and upper quartile values of monthly mean streamflow, by station and 11-water-year period, for the Platte River gaging stations from Duncan through Louisville, Nebraska, 1895-2006.

[Tabled values are streamflow in cubic feet per second; NC, not computed]

\begin{tabular}{|c|c|c|c|c|c|c|c|}
\hline Station name & Period of water years & January & February & March & April & May & June \\
\hline \multirow[t]{4}{*}{ Duncan } & $1895-1905$ & $\mathrm{NC}$ & $\mathrm{NC}$ & $2,817-9,688$ & $4,339-8,136$ & $5,430-11,568$ & $8,362-14,689$ \\
\hline & 1934-1944 & $42-2,000$ & $616-2,161$ & $1,226-3,362$ & $560-1,868$ & $236-3,172$ & $274-1,491$ \\
\hline & 1966-1976 & $1,205-1,863$ & $1,691-3,076$ & $1,813-3,686$ & $1,736-2,817$ & $1,001-3,092$ & $733-7,866$ \\
\hline & 1985-1995 & $1,664-2,734$ & $1,893-3,225$ & $2,118-5,535$ & $1,439-2,944$ & $1,239-3,600$ & $956-3,048$ \\
\hline \multirow[t]{3}{*}{ North Bend } & 1895-1905 & $\mathrm{NC}$ & $\mathrm{NC}$ & $5,633-19,376$ & $8,678-16,965$ & $10,860-21,866$ & $16,781-26,751$ \\
\hline & 1934-1944 & $1,951-3,559$ & $2,575-4,709$ & $3,611-7,313$ & $3,327-4,709$ & $2,885-7,897$ & $3,583-6,361$ \\
\hline & $1951-1961$ & $2,461-3,692$ & $3,493-6,918$ & $6,409-9,145$ & $5,120-8,240$ & $5,604-7,757$ & $5,232-8,866$ \\
\hline \multirow[t]{5}{*}{ Leshara } & 1934-1944 & $1,766-2,367$ & $2,211-5,672$ & $2,010-3,732$ & $1,361-3,077$ & $2,379-4,148$ & $2,845-4,767$ \\
\hline & $1951-1961$ & $2,496-3,657$ & $3,467-6,597$ & $6,454-9,407$ & $5,154-8,325$ & $5,644-7,696$ & $5,348-9,867$ \\
\hline & $1966-1976$ & $2,810-3,356$ & $3,742-7,688$ & $5,067-9,372$ & $4,391-5,645$ & $3,055-7,154$ & $3,421-11,882$ \\
\hline & $1985-1995$ & $3,405-5,319$ & $4,981-6,656$ & $6,216-10,276$ & $4,895-7,821$ & $3,825-8,537$ & $3,116-8,174$ \\
\hline & 1996-2006 & $2,061-5,352$ & $3,154-7,697$ & $4,122-7,203$ & $3,609-8,526$ & $3,392-7,668$ & $2,790-9,289$ \\
\hline Ashland & $1895-1905$ & $\mathrm{NC}$ & $\mathrm{NC}$ & $\mathrm{NC}$ & $6,607-14,322$ & $11,768-22,758$ & $18,262-21,102$ \\
\hline \multirow[t]{5}{*}{ Louisville } & $1934-1944$ & $1,993-3,768$ & $2,497-5,672$ & $5,478-8,474$ & $4,073-5,597$ & $3,813-10,516$ & $4,204-13,312$ \\
\hline & $1951-1961$ & $2,471-4,280$ & $3,596-7,434$ & $6,616-12,345$ & $5,050-10,666$ & $6,397-11,255$ & $5,585-12,858$ \\
\hline & 1966-1976 & $3,516-4,129$ & $4,943-10,563$ & $6,420-14,788$ & $5,769-10,204$ & $4,589-11,589$ & $4,520-16,115$ \\
\hline & 1985-1995 & $6,456-12,277$ & $7,607-13,511$ & $9,118-24,839$ & $6,705-18,913$ & $7,926-14,899$ & $6,596-16,572$ \\
\hline & 1996-2006 & $3,148-6,597$ & $4,495-10,321$ & $5,906-11,244$ & $6,296-13,457$ & $6,187-14,140$ & $6,078-18,618$ \\
\hline
\end{tabular}


Appendix 3. Lower and upper quartile values of monthly mean streamflow, by station and 11-water-year period, for the Platte River gaging stations from Duncan through Louisville, Nebraska, 1895-2006.-Continued

[Tabled values are streamflow in cubic feet per second; NC, not computed]

\begin{tabular}{|c|c|c|c|c|c|c|c|}
\hline Station name & Period of water years & July & August & September & October & November & December \\
\hline \multirow[t]{4}{*}{ Duncan } & 1895-1905 & $2,903-5,850$ & $414-3,514$ & $459-1,175$ & $613-1,060$ & $735-1,463$ & $\mathrm{NC}$ \\
\hline & 1934-1944 & $3-658$ & $0-6$ & $0-237$ & $0-394$ & $1-936$ & $5-1,498$ \\
\hline & 1966-1976 & $71-2,249$ & $97-480$ & $219-668$ & $986-1,835$ & $1,166-2,071$ & $1,266-1,952$ \\
\hline & 1985-1995 & $973-1,782$ & $581-1,547$ & $684-2,032$ & $675-3,056$ & $940-2,503$ & $1,119-2,632$ \\
\hline \multirow[t]{3}{*}{ North Bend } & $1895-1905$ & $5,805-12,188$ & $862-6,989$ & $918-2,349$ & $1,227-2,121$ & $1,469-2,926$ & $\mathrm{NC}$ \\
\hline & 1934-1944 & $1,262-3,374$ & $963-1,604$ & $1,560-2,756$ & $1,663-2,372$ & $1,977-2,798$ & $1,822-3,253$ \\
\hline & 1951-1961 & $2,195-6,093$ & $1,972-4,764$ & $1,594-3,241$ & $2,192-3,926$ & $3,439-4,417$ & $2,810-4,354$ \\
\hline \multirow[t]{5}{*}{ Leshara } & 1934-1944 & $1,345-3,892$ & $940-3,234$ & $1,726-3,532$ & $2,371-5,121$ & $1,559-4,532$ & $2,486-5,174$ \\
\hline & $1951-1961$ & $2,298-6,360$ & $2,024-4,874$ & $1,603-3,335$ & $2,206-3,920$ & $3,508-4,461$ & $2,786-4,390$ \\
\hline & 1966-1976 & $1,293-4,699$ & $825-2,021$ & $1,248-2,551$ & $2,746-4,628$ & $3,257-4,982$ & $3,143-3,966$ \\
\hline & 1985-1995 & $2,420-6,125$ & $1,720-5,523$ & $2,687-5,661$ & $3,452-5,911$ & $3,806-5,192$ & $3,529-5,936$ \\
\hline & 1996-2006 & $1,613-3,811$ & $1,222-5,348$ & $1,923-5,139$ & $2,458-5,983$ & $3,001-6,150$ & $2,835-5,523$ \\
\hline Ashland & $1895-1905$ & $10,060-21,945$ & $2,262-11,894$ & $2,056-5,600$ & $3,111-5,633$ & $1,971-5,496$ & $\mathrm{NC}$ \\
\hline \multirow[t]{5}{*}{ Louisville } & 1934-1944 & $1,768-5,363$ & $1,458-2,331$ & $1,772-3,454$ & $1,800-2,918$ & $2,388-3,194$ & $2,013-3,695$ \\
\hline & $1951-1961$ & $2,273-6,083$ & $1,952-5,614$ & $1,624-2,889$ & $2,247-3,858$ & $3,525-4,307$ & $2,815-4,576$ \\
\hline & 1966-1976 & $2,381-5,849$ & $1,256-2,982$ & $1,546-3,274$ & $3,366-5,942$ & $3,840-6,310$ & $3,559-5,216$ \\
\hline & 1985-1995 & $5,135-12,759$ & $2,288-8,170$ & $4,015-10,552$ & $4,205-9,261$ & $4,842-9,992$ & $5,723-10,906$ \\
\hline & 1996-2006 & $3,105-6,840$ & $2,168-8,329$ & $2,435-6,953$ & $3,089-7,613$ & $3,998-8,264$ & $4,049-6,817$ \\
\hline
\end{tabular}


Appendix 4. Lower and upper quartile values of monthly maximum streamflow, by station and 11-water-year period, for the Platte River gaging stations from Duncan through Louisville, Nebraska, 1895-2006.

[Tabled values are streamflow in cubic feet per second; NC, not computed]

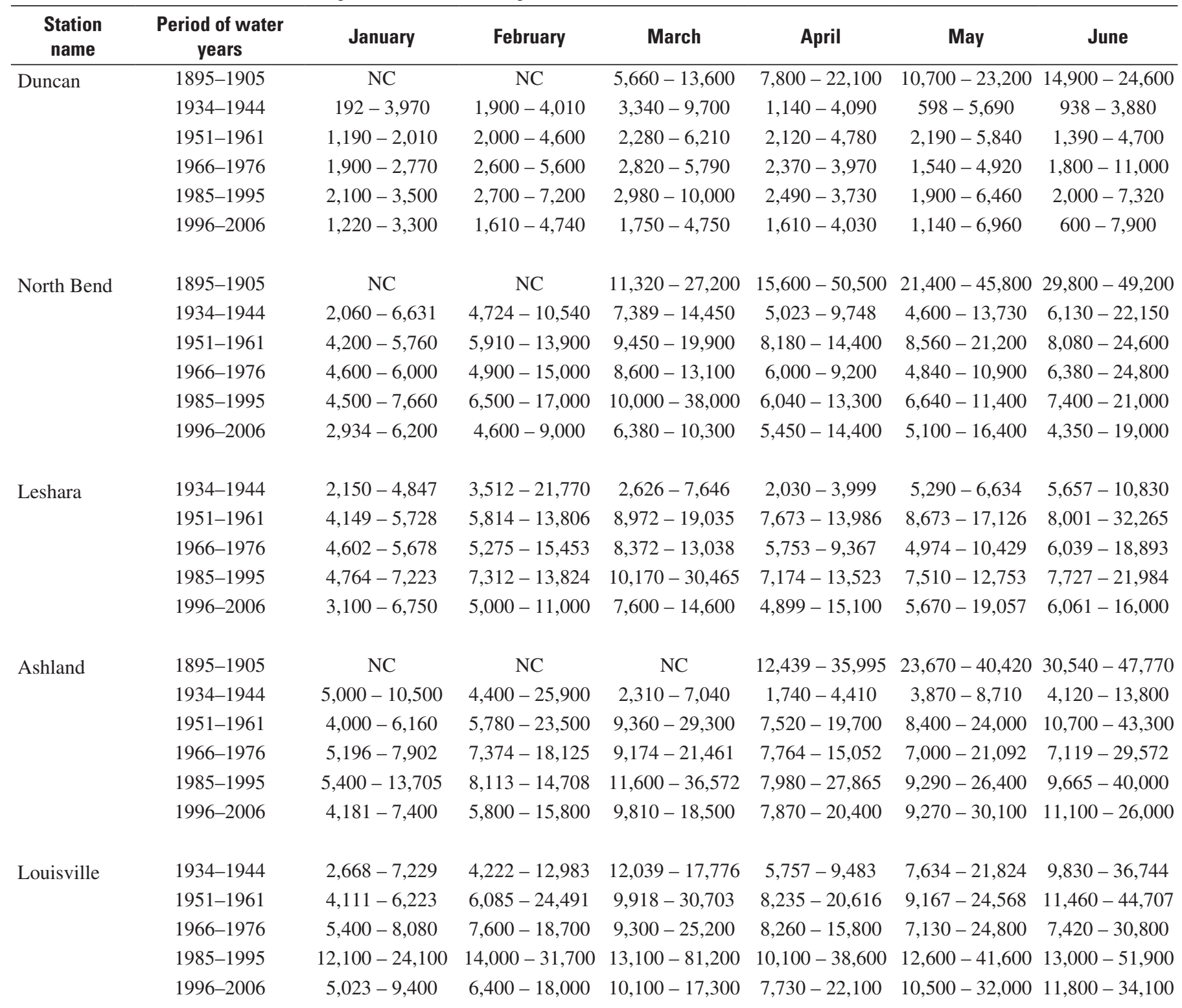


Appendix 4. Lower and upper quartile values of monthly maximum streamflow, by station and 11-water-year period, for the Platte River gaging stations from Duncan through Louisville, Nebraska, 1895-2006.-Continued

[Tabled values are streamflow in cubic feet per second; NC, not computed]

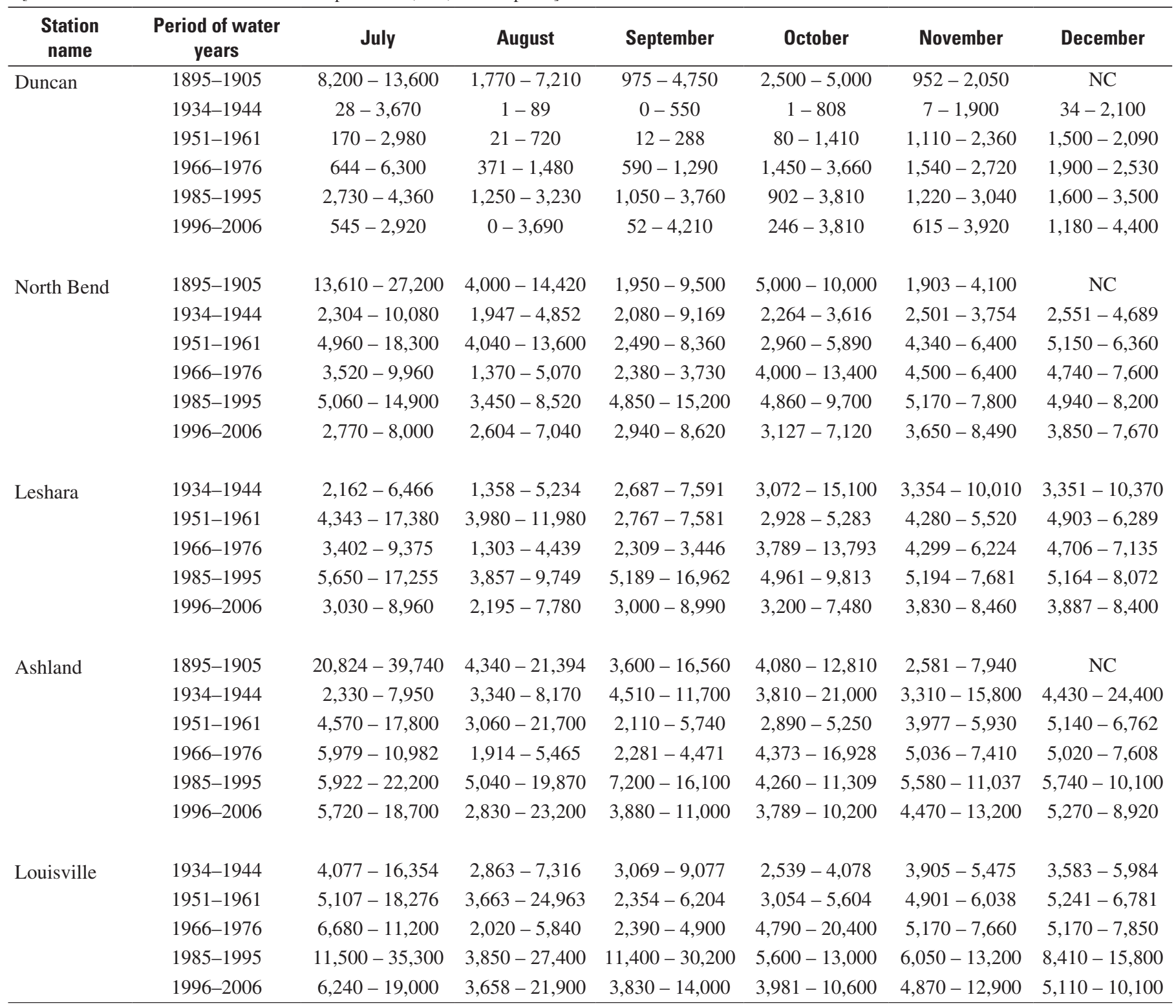


Appendix 5. Lower and upper quartile values of monthly minimum streamflow, by station and 11-water-year period, for the Platte River gaging stations from Duncan through Louisville, Nebraska, 1895-2006.

[Tabled values are streamflow in cubic feet per second; NC, not computed]

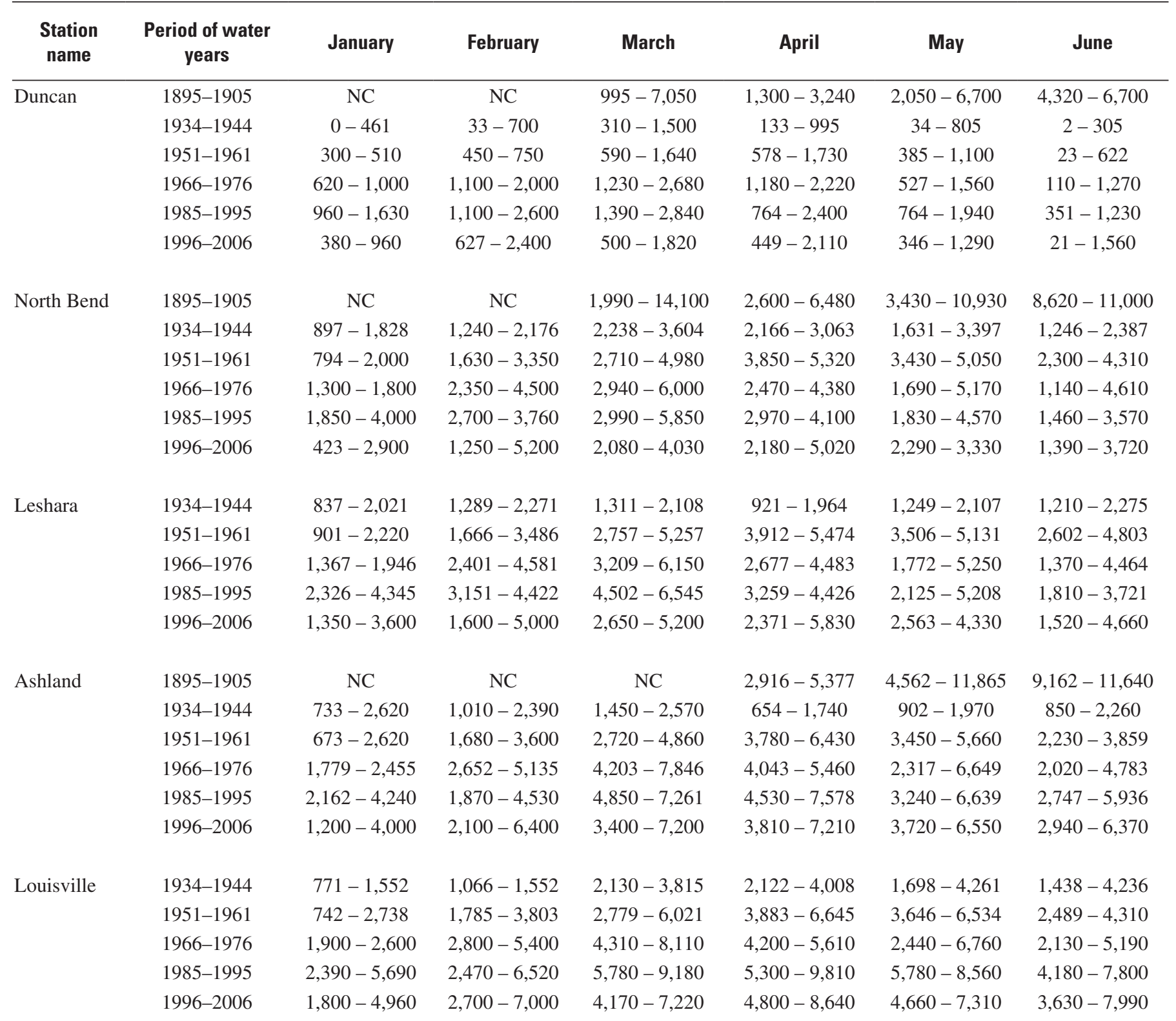


Appendix 5. Lower and upper quartile values of monthly minimum streamflow, by station and 11-water-year period, for the Platte River gaging stations from Duncan through Louisville, Nebraska, 1895-2006. - Continued

[Tabled values are streamflow in cubic feet per second; NC, not computed]

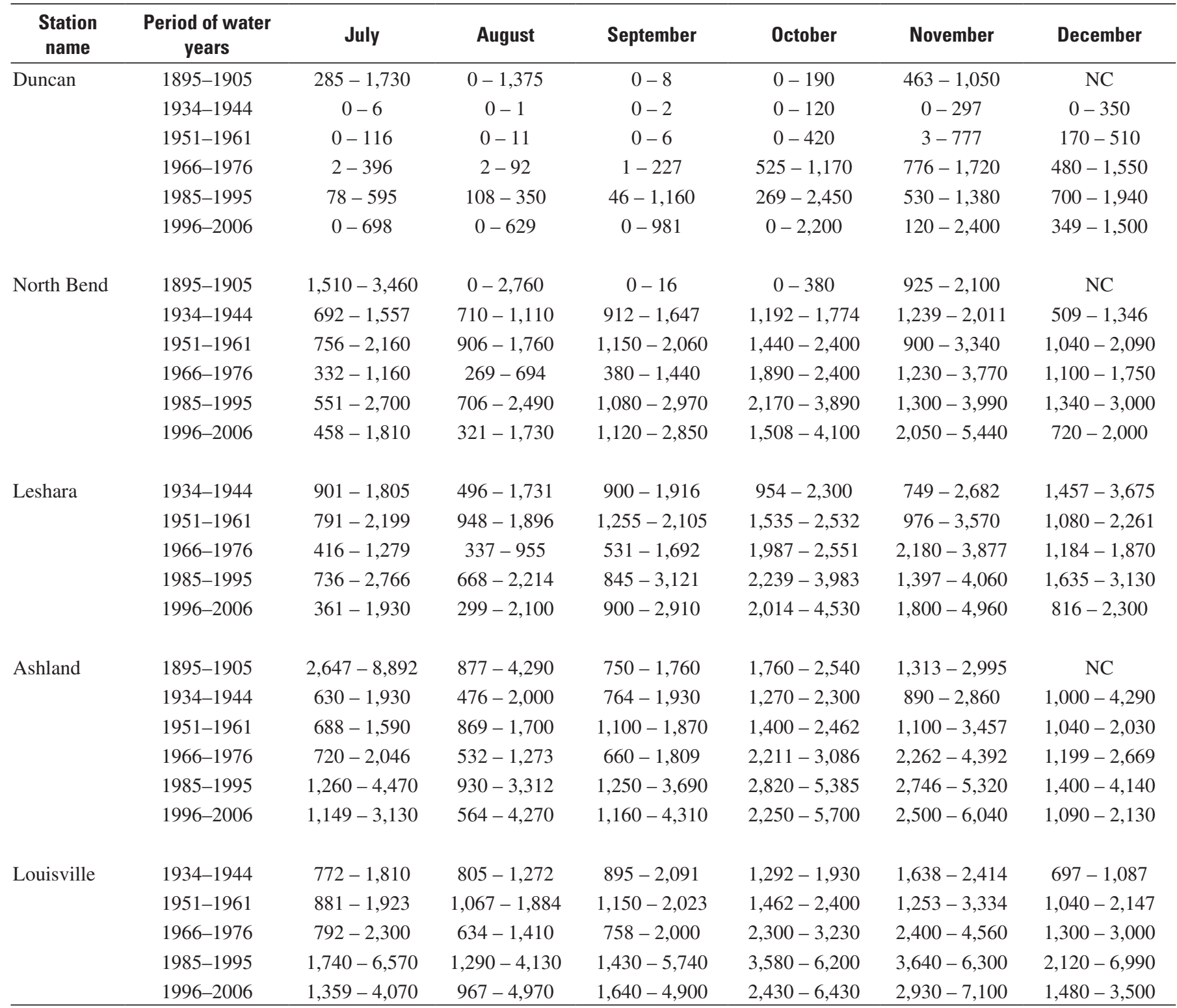


Appendix 6. Lower and upper quartile values of monthly coefficients of skewness of streamflow distribution, by station and 11-water-year period, for the Platte River gaging stations from Duncan through Louisville, Nebraska, 1895-2006.

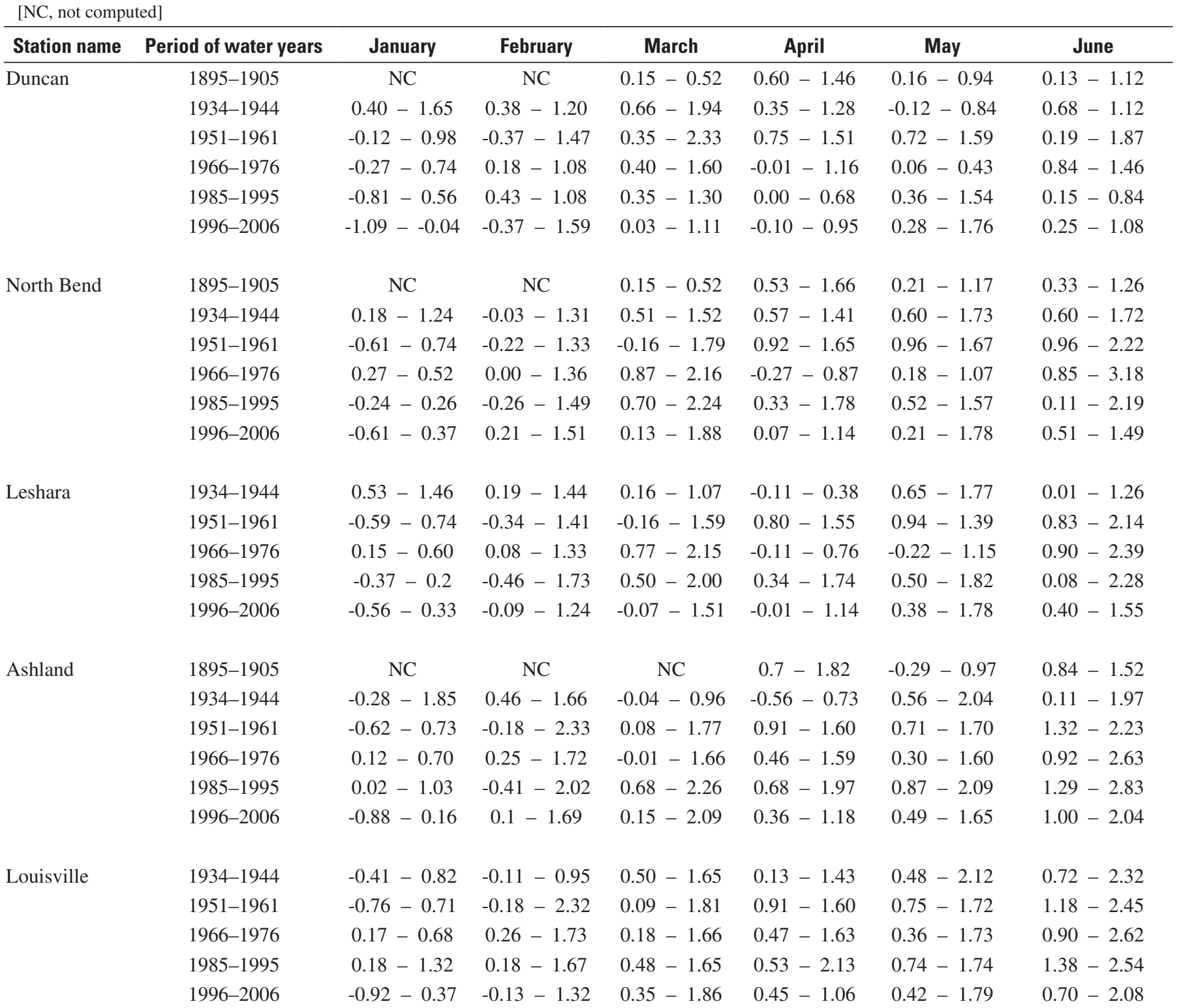


Appendix 6. Lower and upper quartile values of monthly coefficients of skewness of streamflow distribution, by station and 11-water-year period, for the Platte River gaging stations from Duncan through Louisville, Nebraska, 1895-2006.-Continued

\begin{tabular}{|c|c|c|c|c|c|c|}
\hline Period of water years & July & August & September & October & November & December \\
\hline $1895-1905$ & $0.22-1.14$ & $0.26-1.16$ & $0.71-1.35$ & $1.30-1.93$ & $-0.81-0.38$ & $\mathrm{NC}$ \\
\hline 1934-1944 & $1.06-2.31$ & $2.49-4.13$ & $0.49-2.09$ & $1.11-3.17$ & $-0.22-3.72$ & $0.38-1.59$ \\
\hline $1951-1961$ & $1.13-1.84$ & $1.19-3.22$ & $1.28-4.56$ & $0.22-1.07$ & $-1.24-1.04$ & $0.05-1.39$ \\
\hline 1966-1976 & $1.11-2.00$ & $0.51-1.18$ & $-0.07-1.04$ & $-0.02-0.93$ & $-0.29-1.07$ & $-0.64-0.73$ \\
\hline 1985-1995 & $0.66-1.49$ & $0.46-1.83$ & $0.04-0.76$ & $-0.18-0.38$ & $-0.83-0.16$ & $-0.41-0.84$ \\
\hline $1895-1905$ & $0.2-1.05$ & $0.26-1.43$ & $0.71-1.35$ & $1.30-1.93$ & $-0.81-0.38$ & $\mathrm{NC}$ \\
\hline 1934-1944 & $0.83-1.8$ & $0.67-2.57$ & $0.47-2.33$ & $0.60-2.02$ & $-1.17-0.04$ & $-0.52-0.41$ \\
\hline $1951-1961$ & $0.47-2.02$ & $0.91-2.00$ & $0.29-1.87$ & $-0.14-0.48$ & $-0.26-0.59$ & $-0.41-0.34$ \\
\hline 1966-1976 & $0.75-1.84$ & $0.35-1.12$ & $0.06-1.06$ & $0.66-1.70$ & $-0.40-0.63$ & $-0.75-0.93$ \\
\hline 1934-1944 & $0.05-1.34$ & $-0.23-0.92$ & $0.69-2.43$ & $-0.02-1.33$ & $-0.23-1.58$ & $-0.16-2.34$ \\
\hline $1951-1961$ & $0.26-1.55$ & $0.68-1.78$ & $0.26-2.35$ & $-0.35-0.34$ & $-0.28-0.36$ & $-0.38-0.41$ \\
\hline 1966-1976 & $0.72-1.72$ & $0.34-1.06$ & $0.10-0.89$ & $0.69-1.61$ & $-0.4-/ 0.69$ & $-0.8-0.84$ \\
\hline 1985-1995 & $0.52-1.44$ & $0.47-1.66$ & $0.54-1.42$ & $0.25-1.15$ & $-0.73-0.47$ & $-0.58-0.48$ \\
\hline 1996-2006 & $0.60-1.20$ & $-0.16-0.82$ & $-0.06-1.47$ & $-0.09-0.58$ & $-0.90-0.89$ & $-0.74--0.07$ \\
\hline 1895-1905 & $0.19-0.99$ & $0.21-0.40$ & $0.44-1.62$ & $-0.78-1.08$ & $-0.57-0.09$ & $\mathrm{NC}$ \\
\hline 1934-1944 & $0.17-1.11$ & $0.12-1.47$ & $0.59-1.23$ & $-0.06-1.56$ & $0.44-2.13$ & $0.45-1.77$ \\
\hline $1951-1961$ & $0.5-1.41$ & $0.59-1.84$ & $0.37-1.40$ & $-0.06-0.94$ & $-0.34-0.52$ & $-0.65-0.28$ \\
\hline 1966-1976 & $0.72-1.26$ & $0.17-0.76$ & $-0.10-0.76$ & $-0.03-2.23$ & $-0.37-0.68$ & $-0.92-0.78$ \\
\hline 1985-1995 & $0.49-2.22$ & $0.64-2.67$ & $0.79-2.10$ & $0.13-1.57$ & $-0.19-0.69$ & $-1.04-0.97$ \\
\hline 1996-2006 & $0.53-1.98$ & $0.07-2.38$ & $0.58-1.31$ & $-0.32-1.21$ & $0.37-1.64$ & $-1.00--0.39$ \\
\hline
\end{tabular}




\section{Temporal Differences in the Hydrologic Regime of the Lower Platte River, Nebraska, 1895-2006}

Appendix 7. Lower and upper quartile values of monthly coefficients of variation of streamflow, by station and 11-water-year period, for the Platte River gaging stations from Duncan through Louisville, Nebraska, 1895-2006.

[Tabled values are coefficient of variation, in percent; NC, not computed]

\begin{tabular}{|c|c|c|c|c|c|c|c|}
\hline Station name & Period of water years & January & February & March & April & May & June \\
\hline \multirow[t]{6}{*}{ Duncan } & $1895-1905$ & $\mathrm{NC}$ & $\mathrm{NC}$ & $20-49$ & $29-85$ & $37-46$ & $20-37$ \\
\hline & 1934-1944 & $40-120$ & $28-86$ & $38-94$ & $42-64$ & $44-85$ & $58-102$ \\
\hline & $1951-1961$ & $29-49$ & $31-72$ & $26-43$ & $23-36$ & $36-78$ & $50-75$ \\
\hline & 1966-1976 & $24-42$ & $21-33$ & $11-32$ & $12-21$ & $29-49$ & $45-80$ \\
\hline & 1985-1995 & $18-28$ & $23-41$ & $16-58$ & $13-24$ & $26-49$ & $32-81$ \\
\hline & 1996-2006 & $18-31$ & $14-32$ & $12-42$ & $16-41$ & $26-66$ & $34-60$ \\
\hline \multirow[t]{6}{*}{ North Bend } & $1895-1905$ & $\mathrm{NC}$ & $\mathrm{NC}$ & $20-49$ & $29-89$ & $37-51$ & $20-40$ \\
\hline & 1934-1944 & $18-55$ & $35-47$ & $23-55$ & $22-34$ & $29-47$ & $35-53$ \\
\hline & $1951-1961$ & $25-40$ & $21-45$ & $21-45$ & $17-30$ & $28-46$ & $34-81$ \\
\hline & 1966-1976 & $33-44$ & $18-49$ & $13-41$ & $13-25$ & $21-33$ & $29-79$ \\
\hline & $1985-1995$ & $18-28$ & $18-50$ & $24-74$ & $16-29$ & $19-49$ & $30-66$ \\
\hline & 1996-2006 & $15-34$ & $11-51$ & $13-44$ & $16-31$ & $22-59$ & $30-44$ \\
\hline \multirow[t]{5}{*}{ Leshara } & 1934-1944 & $12-44$ & $25-49$ & $17-47$ & $14-38$ & $18-54$ & $30-53$ \\
\hline & 1951-1961 & $25-39$ & $20-45$ & $20-53$ & $17-28$ & $27-43$ & $33-79$ \\
\hline & 1966-1976 & $32-42$ & $18-50$ & $14-39$ & $12-24$ & $17-31$ & $30-73$ \\
\hline & 1985-1995 & $15-23$ & $17-37$ & $22-59$ & $16-26$ & $18-47$ & $29-63$ \\
\hline & 1996-2006 & $13-29$ & $14-41$ & $13-34$ & $13-26$ & $17-56$ & $32-44$ \\
\hline \multirow[t]{6}{*}{ Ashland } & 1895-1905 & $\mathrm{NC}$ & $\mathrm{NC}$ & $\mathrm{NC}$ & $25-68$ & $30-47$ & $23-39$ \\
\hline & 1934-1944 & $33-68$ & $29-62$ & $10-42$ & $13-48$ & $20-65$ & $37-59$ \\
\hline & 1951-1961 & $22-41$ & $21-46$ & $21-55$ & $18-28$ & $33-40$ & $45-77$ \\
\hline & 1966-1976 & $27-53$ & $25-50$ & $20-33$ & $14-25$ & $19-41$ & $34-87$ \\
\hline & 1985-1995 & $18-37$ & $24-45$ & $18-57$ & $16-39$ & $20-56$ & $30-65$ \\
\hline & 1996-2006 & $13-34$ & $15-44$ & $15-51$ & $13-36$ & $21-69$ & $31-47$ \\
\hline \multirow[t]{5}{*}{ Louisville } & 1934-1944 & $31-49$ & $40-72$ & $35-52$ & $19-44$ & $34-49$ & $42-95$ \\
\hline & 1951-1961 & $23-39$ & $21-45$ & $21-57$ & $18-29$ & $32-42$ & $43-75$ \\
\hline & 1966-1976 & $27-52$ & $23-49$ & $19-32$ & $14-25$ & $18-44$ & $34-85$ \\
\hline & 1985-1995 & $29-40$ & $26-47$ & $25-76$ & $16-40$ & $19-54$ & $29-73$ \\
\hline & 1996-2006 & $13-30$ & $11-44$ & $14-43$ & $10-35$ & $22-58$ & $33-46$ \\
\hline
\end{tabular}


Appendix 7. Lower and upper quartile values of monthly coefficients of variation of streamflow, by station and 11-water-year period, for the Platte River gaging stations from Duncan through Louisville, Nebraska, 1895-2006._Continued

[Tabled values are coefficient of variation, in percent; NC, not computed]

\begin{tabular}{|c|c|c|c|c|c|c|c|}
\hline Station name & Period of water years & July & August & September & October & November & December \\
\hline \multirow[t]{6}{*}{ Duncan } & $1895-1905$ & $52-88$ & $46-92$ & $83-102$ & $63-118$ & $7-28$ & $\mathrm{NC}$ \\
\hline & 1934-1944 & $105-183$ & $123-282$ & $61-123$ & $44-258$ & $33-373$ & $41-130$ \\
\hline & $1951-1961$ & $75-125$ & $97-196$ & $81-196$ & $19-86$ & $15-39$ & $29-50$ \\
\hline & 1966-1976 & $83-155$ & $66-97$ & $46-88$ & $17-31$ & $10-19$ & $20-29$ \\
\hline & 1985-1995 & $49-84$ & $54-104$ & $29-76$ & $15-30$ & $17-36$ & $18-37$ \\
\hline & 1996-2006 & $59-154$ & $49-158$ & $27-65$ & $14-29$ & $8-51$ & $14-46$ \\
\hline \multirow[t]{6}{*}{ North Bend } & $1895-1905$ & $49-66$ & $46-98$ & $83-102$ & $63-118$ & $7-28$ & $\mathrm{NC}$ \\
\hline & 1934-1944 & $29-65$ & $17-57$ & $17-53$ & $11-22$ & $10-31$ & $26-43$ \\
\hline & $1951-1961$ & $33-71$ & $33-72$ & $17-51$ & $14-26$ & $12-29$ & $23-50$ \\
\hline & 1966-1976 & $58-83$ & $37-63$ & $21-53$ & $20-34$ & $12-25$ & $24-38$ \\
\hline & 1985-1995 & $47-60$ & $24-44$ & $31-45$ & $14-22$ & $12-39$ & $18-36$ \\
\hline & 1996-2006 & $25-60$ & $29-46$ & $16-44$ & $12-24$ & $11-24$ & $27-48$ \\
\hline \multirow[t]{5}{*}{ Leshara } & 1934-1944 & $15-49$ & $25-47$ & $21-49$ & $28-64$ & $32-55$ & $25-44$ \\
\hline & 1951-1961 & $33-69$ & $31-69$ & $18-43$ & $13-25$ & $10-27$ & $20-47$ \\
\hline & 1966-1976 & $50-80$ & $32-54$ & $18-52$ & $18-29$ & $9-21$ & $24-37$ \\
\hline & 1985-1995 & $51-66$ & $26-45$ & $33-47$ & $14-23$ & $12-37$ & $16-33$ \\
\hline & 1996-2006 & $27-65$ & $24-49$ & $17-51$ & $9-21$ & $12-22$ & $27-42$ \\
\hline \multirow[t]{6}{*}{ Ashland } & 1895-1905 & $42-53$ & $44-47$ & $51-73$ & $21-49$ & $8-29$ & $\mathrm{NC}$ \\
\hline & 1934-1944 & $20-45$ & $30-55$ & $33-59$ & $26-68$ & $24-66$ & $35-61$ \\
\hline & 1951-1961 & $41-67$ & $31-66$ & $20-36$ & $15-24$ & $10-27$ & $23-52$ \\
\hline & 1966-1976 & $47-71$ & $29-58$ & $16-59$ & $17-30$ & $9-20$ & $22-44$ \\
\hline & 1985-1995 & $40-56$ & $27-57$ & $32-51$ & $11-21$ & $10-24$ & $19-38$ \\
\hline & 1996-2006 & $30-55$ & $29-46$ & $13-60$ & $12-16$ & $11-25$ & $24-33$ \\
\hline \multirow[t]{5}{*}{ Louisville } & 1934-1944 & $44-69$ & $36-60$ & $25-49$ & $12-31$ & $11-34$ & $36-47$ \\
\hline & $1951-1961$ & $38-63$ & $33-65$ & $19-35$ & $15-24$ & $12-26$ & $22-50$ \\
\hline & 1966-1976 & $43-65$ & $27-52$ & $17-58$ & $17-53$ & $10-22$ & $21-43$ \\
\hline & 1985-1995 & $42-66$ & $28-71$ & $26-52$ & $10-29$ & $10-20$ & $15-38$ \\
\hline & 1996-2006 & $31-55$ & $29-46$ & $15-55$ & $13-20$ & $9-21$ & $19-32$ \\
\hline
\end{tabular}


Publishing support provided by:

Rolla Publishing Service Center

For more information concerning this publication, contact: Director, USGS Nebraska Water Science Center

5231 S. 19 Street

Lincoln, NE 68512

(402) 328-4100

Or visit the Nebraska Water Science Center Web site at: http://ne.water.usgs.gov 
Back cover.-Map of study area and gaging stations on the Platte River and contributing tributaries, Nebraska. 


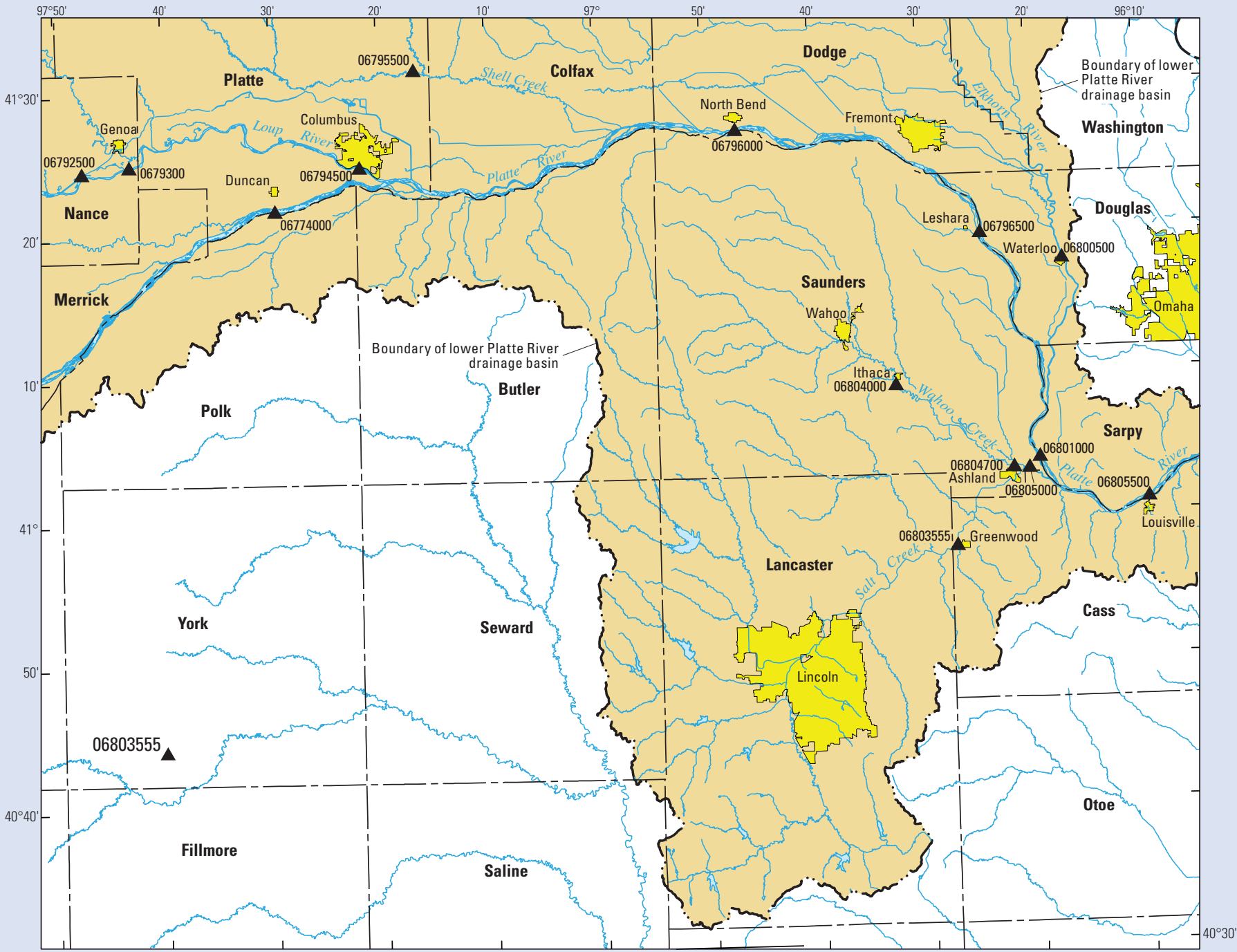

